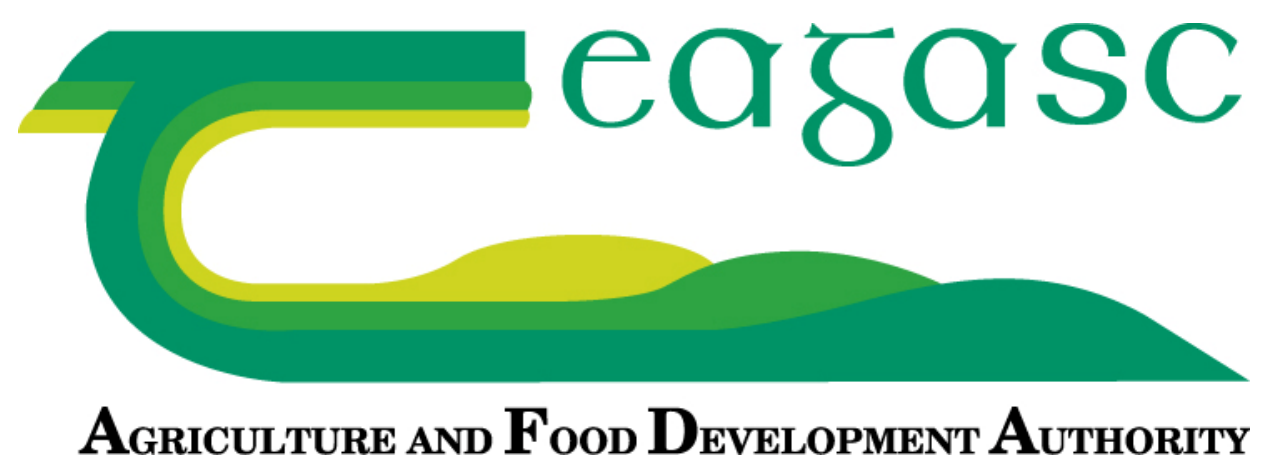

TITLE: A review of nitrous oxide mitigation by farm nitrogen management in temperate grassland-based agriculture

AUTHORS: Dejun Li et al

This article is provided by the author(s) and Teagasc T-Stór in accordance with publisher policies.

Please cite the published version.

The correct citation is available in the T-Stór record for this article.

NOTICE: This is the author's version of a work that was accepted for publication in Journal of Environmental Management. Changes resulting from the publishing process, such as peer review, editing, corrections, structural formatting, and other quality control mechanisms may not be reflected in this document. Changes may have been made to this work since it was submitted for publication. A definitive version was subsequently published in Journal of Environmental Management, (2013), vol 128, pages 893-903. DOI 10.1016/j.jenvman.2013.06.026

This item is made available to you under the Creative Commons Attribution-Non commercial-No Derivatives 3.0 License. 


\section{A review of nitrous oxide mitigation by farm nitrogen management in temperate grassland-based agriculture}

Dejun $\mathrm{Li}^{\mathrm{a}}$, b, c, *

dejunl@gmail.com

Catherine J. Watson ${ }^{\mathrm{d}}$

Mingjia Yan $^{\mathrm{c}}$

Stan Lalor ${ }^{\mathrm{e}}$

Rashid Rafique $^{\mathrm{f}}$

Bernard Hyde ${ }^{g}$

Gary Lanigan ${ }^{\mathrm{e}}$

Karl G. Richards ${ }^{\mathrm{e}}$

Nicholas M. Holden ${ }^{\mathrm{c}}$

James Humphreys ${ }^{\text {b }}$

${ }^{a}$ Key Laboratory of Agro-ecological Processes in Subtropical Region, Institute of Subtropical

Agriculture, Chinese Academy of Sciences, Changsha, Hunan, China

${ }^{\mathrm{b}}$ Livestock Systems Research Department, Animal and Grassland Research and Innovation Centre,

Teagasc, Moorepark, Fermoy, Co. Cork, Ireland

${ }^{\mathrm{c}}$ UCD School of Biosystems Engineering, University College Dublin, Ireland

${ }^{\mathrm{d}}$ Agriculture, Food and Environmental Science Division, Agri-Food and Biosciences Institute,

Belfast, Northern Ireland 
${ }^{\mathrm{e}}$ Environment Soils and Land Use Research Department, Environment Crops and Land Use Research Programme, Teagasc, Johnstown Castle, Wexford, Co. Wexford, Ireland

${ }^{\mathrm{f}}$ Department of Microbiology and Plant Biology, the University of Oklahoma, Norman, Oklahoma, the United States of America

${ }^{\mathrm{g}}$ Environmental Protection Agency, Monaghan, Ireland

*Corresponding author. Key Laboratory of Agro-ecological Processes in Subtropical Region, Institute of Subtropical Agriculture, Chinese Academy of Sciences, Changsha, Hunan, China. Tel.: +86 73184615204 ; fax: +8673184612685. 


\section{Abstract}

Nitrous oxide $\left(\mathrm{N}_{2} \mathrm{O}\right)$ emission from grassland-based agriculture is an important source of atmospheric $\mathrm{N}_{2} \mathrm{O}$. It is hence crucial to explore various solutions including farm nitrogen $(\mathrm{N})$ management to mitigate $\mathrm{N}_{2} \mathrm{O}$ emissions without sacrificing farm profitability and food supply. This paper reviews major $\mathrm{N}$ management practices to lower $\mathrm{N}_{2} \mathrm{O}$ emission from grassland-based agriculture. Restricted grazing by reducing grazing time is an effective way to decrease $\mathrm{N}_{2} \mathrm{O}$ emissions from excreta patches. Balancing the protein-to-energy ratios in the diets of ruminants can also decrease $\mathrm{N}_{2} \mathrm{O}$ emissions from excreta patches. Among the managements of synthetic fertilizer $\mathrm{N}$ application, only adjusting fertilizer $\mathrm{N}$ rate and slow-released fertilizers are proven to be effective in lowering $\mathrm{N}_{2} \mathrm{O}$ emissions. Use of bedding materials may increase $\mathrm{N}_{2} \mathrm{O}$ emissions from animal houses. Manure storage as slurry, manipulating slurry $\mathrm{pH}$ to values lower than 6 and storage as solid manure under anaerobic conditions help to reduce $\mathrm{N}_{2} \mathrm{O}$ emissions during manure storage stage. For manure land application, $\mathrm{N}_{2} \mathrm{O}$ emissions can be mitigated by reducing manure $\mathrm{N}$ inputs to levels that satisfy grass needs. Use of nitrification inhibitors can substantially lower $\mathrm{N}_{2} \mathrm{O}$ emissions associated with applications of fertilizers and manures and from urine patches. $\mathrm{N}_{2} \mathrm{O}$ emissions from legume based grasslands are generally lower than fertilizer-based systems. In conclusion, effective measures should be taken at each step during $\mathrm{N}$ flow or combined options should be used in order to mitigate $\mathrm{N}_{2} \mathrm{O}$ emission at the farm level.

Keywords: Nitrous oxide; mitigation options; temperate grassland; N management 


\section{Introduction}

Nitrous oxide $\left(\mathrm{N}_{2} \mathrm{O}\right)$ is a potent greenhouse gas $(\mathrm{GHG})$ with a global warming potential 298 times higher than carbon dioxide $\left(\mathrm{CO}_{2}\right)$ over a 100-year time horizon (Solomon et al., 2007). It is the third most important anthropogenic GHG and contributed about $6.0 \%$ to the overall global radiative forcing in 2011 (WMO, 2012). In addition, $\mathrm{N}_{2} \mathrm{O}$ currently is the single most important stratospheric ozone-depleting substance and is expected to remain the largest throughout the $21 \mathrm{st}$ century (Ravishankara et al., 2009). Global average mixing ratio of $\mathrm{N}_{2} \mathrm{O}$ has been increasing with a rate of $0.78 \mathrm{ppb} \mathrm{yr}^{-1}$ over the past 10 years (WMO, 2012). The mitigation of $\mathrm{N}_{2} \mathrm{O}$ emissions has been regarded as one of the major choices to combat climate change and has received much attention (Reay et al., 2012; Smith et al., 2012).

The challenges for mitigating $\mathrm{N}_{2} \mathrm{O}$ emissions are substantially different from those for $\mathrm{CO}_{2}$ and methane $\left(\mathrm{CH}_{4}\right)$ because on one hand about $90 \%$ of anthropogenic $\mathrm{N}_{2} \mathrm{O}$ emissions are from the agricultural sector while on the other hand nitrogen $(\mathrm{N})$ is essential for food production (IPCC, 2007; Davidson, 2012). The increase in $\mathrm{N}_{2} \mathrm{O}$ emissions from agriculture is largely induced by the elevated $\mathrm{N}$ inputs via synthetic fertilizer $\mathrm{N}$ or manure (Davidson, 2009). However, to meet the nutritional needs of a growing human population more $\mathrm{N}$ inputs to agriculture are likely needed (Davidson, 2012). $\mathrm{N}_{2} \mathrm{O}$ is produced mainly by two biological processes during $\mathrm{N}$ cycling, i.e., nitrification and denitrification, which is stimulated by $\mathrm{N}$ surplus between $\mathrm{N}$ input and crop demand (Smith et al., 2008). $\mathrm{N}_{2} \mathrm{O}$ emissions are supposed to be reduced by increasing $\mathrm{N}$ use efficiency (NUE, percentage of applied $\mathrm{N}$ taken up by the crop), which seldom exceeds 50\% (Davidson, 2012). N management to increase NUE has been recognized as an effective way to mitigate $\mathrm{N}_{2} \mathrm{O}$ emissions from agriculture (Smith et al., 2008). 
Globally, grassland-based agriculture is the major part in agriculture sector with permanent pastures responsible for $68 \%$ of all the agricultural land (FAO, 2009). Synthetic fertilizer N and manure are widely used to sustain farm productivity in intensively or semi-intensively managed grassland systems. In extensively managed grasslands a large proportion of $\mathrm{N}_{2} \mathrm{O}$ emissions are from excreta deposited by grazing livestock, mostly from urine patches. In New Zealand and Australia, for example, where extensive grassland management is characterised as year-round grazing of grass-clover pastures and very low input of fertilizer $\mathrm{N}$, direct $\mathrm{N}_{2} \mathrm{O}$ emissions from excreta recycled to the soil surface by grazing livestock contributed between $50 \%$ and $60 \%$ of the direct $\mathrm{N}_{2} \mathrm{O}$ emissions and up to $80 \%$ when indirect emissions (from $\mathrm{NH}_{3}$ volatilization and $\mathrm{NO}_{3}{ }^{-}$leaching) are included (de Klein et al., 2001; deKlein et al., 2005). The second largest source, fertilizer N, contributed no more than $15 \%$ (de Klein et al., 2008). In more intensive managed systems with greater reliance on inputs of fertilizer $\mathrm{N}$, the contribution of excreta recycled by grazing livestock can also be considerable. For example, in the Netherlands, Schils et al. (2005) reported that N recycled by grazing livestock accounted for $44 \%$ of total $\mathrm{N}_{2} \mathrm{O}$ emissions compared to $22 \%$ from fertilizer $\mathrm{N}, 14 \%$ from soil and $11 \%$ from manure management in an intensive grassland-based dairy production system receiving total annual inorganic $\mathrm{N}$ inputs of $275 \mathrm{~kg} \mathrm{ha}^{-1}$. Indirect emissions of $\mathrm{N}_{2} \mathrm{O}$ from leached nitrate and from volatilized $\mathrm{NH}_{3}$ accounted for $9 \%$ of total emissions (Schils et al., 2005).

During the past two decades, a few reviews about $\mathrm{N}_{2} \mathrm{O}$ mitigation or $\mathrm{N}$ losses related to grassland-based agriculture systems have been conducted, including $\mathrm{N}_{2} \mathrm{O}$ mitigation from herbivore production systems (Schils et al., 2011), GHG and $\mathrm{NH}_{3}$ emissions from organic mixed crop-dairy systems (Novak et al., 2011), GHG emissions from manure management (Chadwick et al., 2011), $\mathrm{NH}_{3}$ and $\mathrm{N}_{2} \mathrm{O}$ emissions with different manure application methods (Webb et al., 2010). In this 
review, major choices of $\mathrm{N}$ management on grassland farms were evaluated with respect to their effectiveness to mitigate $\mathrm{N}_{2} \mathrm{O}$ emissions. The knowledge synthesized in the review will be useful for identifying potential cost-effective and sustainable ways to mitigate $\mathrm{N}_{2} \mathrm{O}$ emissions from grassland-based agriculture under temperate conditions.

\section{Mechanisms underlying nitrous oxide emissions from grassland}

The emission of $\mathrm{N}_{2} \mathrm{O}$ arises from microbial nitrification and denitrification of inorganic $\mathrm{N}$ in the soil, which in turn is derived from excreta deposited by grazing livestock, application of synthetic fertilizers and manures, and biological N fixation (BNF) (Fig. 1). Nitrification consists of two steps, $\mathrm{NH}_{4}{ }^{+}$oxidation to $\mathrm{NO}_{2}{ }^{-}$and $\mathrm{NO}_{2}{ }^{-}$oxidation to $\mathrm{NO}_{3}{ }^{-}$, carried out by ammonium-oxidizers and nitrite-oxidizers, respectively (Ward, 2000). Denitrification is the anaerobic microbial reduction of $\mathrm{NO}_{3}{ }^{-}$to dinitrogen $\left(\mathrm{N}_{2}\right)$. During the denitrification process, $\mathrm{NO}_{3}{ }^{-}$is successively reduced to $\mathrm{NO}_{2}{ }^{-}$, $\mathrm{NO}, \mathrm{N}_{2} \mathrm{O}$ and finally dinitrogen $\left(\mathrm{N}_{2}\right)$. Since $\mathrm{N}_{2} \mathrm{O}$ is an intermediate during denitrification, it can be both produced and consumed. Nitrification and denitrification are tightly coupled since $\mathrm{NO}_{2}^{-}$or $\mathrm{NO}_{3}{ }^{-}$produced during nitrification can be utilized by denitrifiers and this coupling can take place in soils where favourable conditions for both nitrification and denitrification are present in neighbouring microhabitats (Wrage et al., 2001). However, under oxygen $\left(\mathrm{O}_{2}\right)$ limiting conditions, $\mathrm{NH}_{4}{ }^{+}$may be oxidized to $\mathrm{NO}_{2}^{-}$and then sequentially reduced to $\mathrm{NO}, \mathrm{N}_{2} \mathrm{O}$ and $\mathrm{N}_{2}$. This process, which is carried out by autotrophic ammonium-oxidizers is termed nitrifier denitrification (Wrage et al., 2001). The relationships between nitrification, denitrification and nitrifier denitrification are shown in Fig. 1. In addition to the above micro-organism mediated processes, some abiotic processes (mostly chemodenitrification) may also contribute to the production of $\mathrm{N}_{2} \mathrm{O}$ under certain 
conditions (Williams et al., 1992). Current evidence indicates that most of the $\mathrm{N}_{2} \mathrm{O}$ evolved from soils is produced by biological processes and that little is produced by chemodenitrification (Bremner, 1997).

\section{Potential $\mathrm{N}_{2} \mathrm{O}$ mitigation options by farm $\mathrm{N}$ management}

\subsection{Options to lower $\mathrm{N}_{2} \mathrm{O}$ emissions from excreta patches}

Urine and dung patches on grasslands represent high (up to more than $1000 \mathrm{~kg} \mathrm{~N} \mathrm{ha}^{-1}$ ), random and very local additions of $\mathrm{N}$ and readily available carbon (C) that can create optimal conditions for $\mathrm{N}_{2} \mathrm{O}$ production (van Groenigen et al., 2005). It was estimated that between 0.1 and $3.8 \%$ of urine- $\mathrm{N}$ and between 0.1 and $0.7 \%$ of the dung- $\mathrm{N}$ is emitted to the atmosphere as $\mathrm{N}_{2} \mathrm{O}$ (Oenema et al., 1997). In countries that depend economically to a large extent on livestock farming, these fluxes are major contribution to the national GHG budget. It is therefore imperative to seek measures lower $\mathrm{N}_{2} \mathrm{O}$ emissions from excreta patches.

\subsubsection{Restricted grazing}

Restricting grazing has been proposed as an option to reduce $\mathrm{N}_{2} \mathrm{O}$ and other $\mathrm{GHG}$ emissions (Oenema et al., 2001; Schils et al., 2006; de Klein et al. 2006; Luo et al. 2008). This management tactic involves a reduction in grazing time or livestock number, each of which results in decreased dung and urine deposition. Therefore there is a great potential to lower $\mathrm{N}_{2} \mathrm{O}$ emissions via decrease in excreta deposition to pasture. In Ireland, there has been a $14 \%$ reduction in GHG emissions 
associated with dung and urine deposited by grazing livestock since 1998, mainly due to decreased livestock numbers, particularly sheep, arising from the policy of extensification driven by the Common Agricultural Policy (CAP) (Humphreys, 2008). Although both $\mathrm{N}_{2} \mathrm{O}$ and GHG emissions could be mitigated by decreased livestock numbers, this option would mean a profound decrease in the farm profitability. In addition, the growing human population requires continuing increase in animal protein consumption, as it was projected that animal numbers will increase by $40 \%$ between 2000 and 2030 (Oenema et al., 2005). So reducing numbers of animals to lower $\mathrm{N}_{2} \mathrm{O}$ emissions is unlikely to be acceptable.

A compromise way to restrict grazing is to reduce grazing time within a year. With this practice, animals are kept off grazing paddocks and kept on stand-off/feed pads or in animal houses at a period when it leads to greatest $\mathrm{N}$ losses, so excreta deposition is reduced (Luo et al., 2010). This practice provides opportunity for controlling $\mathrm{N}$ losses, as the animal excreta is collected and can be applied evenly to the pasture at targeted rates and optimum time when the risk for $\mathrm{N}$ losses is minimal (van der Meer, 2008). Recent research by Kennedy et al. (2009) has shown that dairy cows given restricted access time ( $9 \mathrm{~h}$ per day) to pasture under unfavourable conditions for grazing had similar pasture intake and milk production to that of unrestricted dairy cows. In the study, restricted cows were kept indoors and did not receive alternative feed to replace the grazed pasture. Excreta generated indoors were collected, stored and applied mechanically under favourable conditions for herbage production. When slurry is applied mechanically it is generally more evenly distributed than when it is deposited by grazing animals; hence, the $\mathrm{N}$ contained within the slurry is used with greater efficiency and accordingly with less $\mathrm{N}_{2} \mathrm{O}$ loss. There is an economic incentive to impose this management practice during periods when soils are vulnerable to poaching damage and there is a spin-off benefit in terms of $\mathrm{N}_{2} \mathrm{O}$ emissions. Reductions in total direct and indirect $\mathrm{N}_{2} \mathrm{O}$ emissions of 
7 to $11 \%$ have been reported when conventional grazing management was partially replaced by restricted grazing during the wetter months of the year in New Zealand (de Klein et al., 2006; Luo et al., 2008b).

\subsubsection{Dietary manipulation or additives}

There is an exponential relationship between $\mathrm{N}$ intake and $\mathrm{N}$ excretion in urine (Ledgard et al., 2009). Ruminants on lush spring pasture commonly ingest protein in excess of their requirements, but are usually energy limited, resulting in higher ruminal ammonia concentrations being excreted in the urine as urea (Whitehead, 1995). Therefore, balancing the protein-to-energy ratios in the diets of ruminants is important in minimizing the $\mathrm{N}_{2} \mathrm{O}$ emissions resulting from excess urinary $\mathrm{N}$ excretion (Eckard et al., 2010). Dairy cows fed a 14\% crude protein (CP) diet excreted $45 \%$ less urinary $\mathrm{N}$ than did dairy cows fed a $19 \% \mathrm{CP}$ diet (Misselbrook et al., 2005). To reduce the $\mathrm{N}$ content in the diet has been proposed as the most efficient way to reduce the amount of excreta N,

whilst maintaining animal production (Ledgard, 2001; de Klein et al., 2005). The premise of this practice is that pasture typically contains an excess of protein relative to animal requirements and supplements with a low protein concentration (e.g. maize silage) can increase efficiency of $\mathrm{N}$ utilization (Kebreab et al., 2001). With this practice, low-protein forage such as maize silage is normally used to reduce dietary $\mathrm{N}$ concentration so that to increase $\mathrm{N}$ use efficiency and reduce environmental $\mathrm{N}$ emissions (Luo et al., 2008a). By reducing the protein content of supplement feed, a $20 \%$ reduction in estimated $\mathrm{N}$ excretion to urine and faeces was achieved (Nielsen et al., 2003). The limited information available supports the efficiency of such management practices on total $\mathrm{N}_{2} \mathrm{O}$ emissions from whole farm systems. For example, total $\mathrm{N}_{2} \mathrm{O}$ emission from the dairy farm 
systems consisted of a maize supplementation system with a stocking rate of 3.8 cows ha $^{-1}$ of grazed pasture with maize silage brought in was slightly lower than a control system with a stocking rate of 3.0 cows ha ${ }^{-1}$ of grazed pasture; but the $\mathrm{N}_{2} \mathrm{O}$ emission per kg of milk production from the maize supplementation was $22 \%$ lower than that from the control system (Luo et al., 2008a).

A controversial option of dietary manipulation is to use hippuric acid, which is a ruminant urine constituent. Ruminants fed with protein rich feeds have been shown to have higher urinary hippuric acid concentrations than ruminants with lower protein diets, so that the concentration of hippuric acid in urine may be changed by manipulating pasture species composition (Clough et al., 2009). Several laboratory-based studies reported significant decline (48-54\%) in cumulative $\mathrm{N}_{2} \mathrm{O}$ emissions from synthetic urine by hippuric acid addition (van Groenigen et al., 2005; Kool et al., 2006). However, according to a field study, increasing hippuric acid addition in bovine urine had no effect on $\mathrm{N}_{2} \mathrm{O}$ mitigation (Clough et al., 2009). Further studies are needed to determine the potential of hippuric acid as an option for $\mathrm{N}_{2} \mathrm{O}$ mitigation.

Supplementing a diuretic in the form of salt $(\mathrm{NaCl})$ to a cow's diet has been suggested as a potential mitigation option to reduce $\mathrm{N}$ loss as $\mathrm{N}_{2} \mathrm{O}$ and nitrate due to increase in the spread of urine, thereby diluting the rate of urinary-N and increasing plant uptake of $\mathrm{N}$ (Ledgard et al., 2007). However the results are not consistent between laboratory and field experiments. $\mathrm{N}_{2} \mathrm{O}$ emission was reduced only in laboratory study but not in field study (van Groenigen et al., 2006). More assessments are needed for this option.

\subsection{Management of synthetic fertilizer $\mathrm{N}$ application}


Synthetic fertilizer $\mathrm{N}$ application in agriculture is one of the important factors leading to the rapid increase of atmospheric $\mathrm{N}_{2} \mathrm{O}$ concentration in recent decades (Davidson, 2009). Fertilizer $\mathrm{N}$ rate, type, timing, and placement have all been proposed to influence $\mathrm{N}_{2} \mathrm{O}$ flux from agricultural soils (Millar et al., 2010) and provide potential for emission abatement (Smith et al., 2007). Nevertheless, only fertilizer $\mathrm{N}$ rate is used to calculate national $\mathrm{N}_{2} \mathrm{O}$ emissions regardless of fertilizer $\mathrm{N}$ type, timing and placement for the IPCC guidelines (IPCC, 2006).

\subsubsection{Fertilizer $\mathbf{N}$ type}

Major fertilizer $\mathrm{N}$ types include anhydrous ammonia, ammonium-based fertilizers, ammonium nitrate, calcium ammonium nitrate, nitrate-based fertilizers, ammonium phosphates, urea, urea-ammonium nitrate (Bouwman et al., 2002). Fertilizer $\mathrm{N}$ type has been reported to affect soil $\mathrm{N}_{2} \mathrm{O}$ emissions (Bouwman et al., 2002; Venterea et al., 2005). $\mathrm{N}_{2} \mathrm{O}$ emissions were 2-4 times greater from treatment amended with anhydrous ammonia than from those amended with urea ammonium nitrate and broadcast urea in a cropland study (Venterea et al., 2005). Bouwman et al. (2002) reported that nitrate based fertilizers resulted in significantly lower emissions of $\mathrm{N}_{2} \mathrm{O}$ than ammonium based fertilizers based on analysis of a global data set. In another data synthesis, Stehfest and Bouwman (2006) concluded there was no significant difference among most fertilizer

types in terms of $\mathrm{N}_{2} \mathrm{O}$ emissions. Since the effect of fertilizer type on $\mathrm{N}_{2} \mathrm{O}$ emission may be confounded, and since very limited studies have been conducted to compare the responses of $\mathrm{N}_{2} \mathrm{O}$ emission to fertilizer type while keeping the same for other factors, more studies are needed before any solid conclusions are drawn. 
A new form of fertilizer $\mathrm{N}$ type has emerged recently to enhance the efficiency of fertilizer $\mathrm{N}$, i.e., slow-released fertilizers which are defined as a fertilizer that release (convert to a plant-available form) their plant nutrients at a slower rate relative to a "reference soluble" product (Hall, 2005). From the perspective of $\mathrm{N}_{2} \mathrm{O}$ mitigation, only the effectiveness of polymer-coated fertilizers (PCFs) have been tested in several studies among the slow-release fertilizers (Akiyama et al., 2010). A comprehensive analysis showed that PCFs significantly reduced $\mathrm{N}_{2} \mathrm{O}$ emissions by $14 \%$ to $58 \%$ with an average of $35 \%$ (Akiyama et al., 2010). However, most of the existing studies were conducted in cropland, whether PCFs have similar efficiency in reducing $\mathrm{N}_{2} \mathrm{O}$ emissions needed further evaluation.

\subsubsection{Timing of fertilization}

Synchronous timing of fertilizer $\mathrm{N}$ application with plant $\mathrm{N}$ demand is an important measure to improve $\mathrm{N}$ use efficiency (NUE) and thus reduce $\mathrm{N}$ loss to the environment (Crews et al., 2005). However, measures for synchronizing $\mathrm{N}$ supply are often aimed to reduce $\mathrm{N}$ loss via $\mathrm{NH}_{3}$ volatilization and nitrate leaching, which in total account for up to $50 \%$ of $\mathrm{N}$ inputs. Limited data are available to show whether synchrony of nitrogen supply declines soil $\mathrm{N}_{2} \mathrm{O}$ emission from grassland. Based on studies in cropland, it seems that improving NUE cannot consistently reduce $\mathrm{N}_{2} \mathrm{O}$ emissions (Phillips et al., 2009), probably because the practices that improve NUE by reducing $\mathrm{NH}_{3}$ and/or $\mathrm{NO}_{3}{ }^{-}$losses may make more $\mathrm{N}$ available in the soil for both $\mathrm{N}$ uptake in crops and soil $\mathrm{N}_{2} \mathrm{O}$ production (Venterea et al., 2012). In conclusion, current evidence does not support synchronous timing of fertilizer $\mathrm{N}$ application is an effective way to decrease soil $\mathrm{N}_{2} \mathrm{O}$ emission.

\subsubsection{Fertilizer $N$ placement}


Very few studies have been conducted to investigate the effect of fertilizer placement on soil $\mathrm{N}_{2} \mathrm{O}$ emission for grassland. The studies in cropland show that fertilizer placement affects soil $\mathrm{N}_{2} \mathrm{O}$ emission (Liu et al., 2006; Venterea et al., 2008; van Kessel et al., 2013). A meta-analysis shows that placement of fertilizer $\mathrm{N}\left(>5 \mathrm{~cm}\right.$ depth) can be an effective strategy for mitigating $\mathrm{N}_{2} \mathrm{O}$ emissions in no-tillage and reduced tillage systems, especially in humid climatic conditions (van Kessel et al., 2013). The underlying mechanism is that both nitrification and denitrification potential tend to decrease rapidly with depth in no-tillage soils, and hence deep $\mathrm{N}$ placement may simply decrease the supply of inorganic $\mathrm{N}$ substrates within the most biologically active zone where they can be converted to $\mathrm{N}_{2} \mathrm{O}$ via nitrification and/or denitrification (van Kessel et al., 2013). However, whether this practice is effective in grassland needs further investigation.

\subsubsection{Fertilizer $N$ rate}

Among the many practices of fertilizer $\mathrm{N}$ management, fertilizer $\mathrm{N}$ rate is likely most straightforward in affecting soil $\mathrm{N}_{2} \mathrm{O}$ emission. Reducing the $\mathrm{N}$ rate is perhaps the only practice that has broad consensus as being generally reliable for reducing $\mathrm{N}_{2} \mathrm{O}$ emissions (Venterea et al., 2012). The Intergovernmental Panel on Climate Change (IPCC) suggests a default linear emission factor of $1 \%$ for fertilizer $\mathrm{N}$ application, regardless of the rate of application (IPCC, 2006). For the few $\mathrm{N}_{2} \mathrm{O}$ response experiments in which more than two levels of $\mathrm{N}$ were applied, $\mathrm{N}_{2} \mathrm{O}$ flux in response to increasing $\mathrm{N}$ rates has been described by both linear (Halvorson et al., 2008) and nonlinear functions (Bouwman et al., 2002; McSwiney et al., 2005; Kim et al., 2010; Hoben et al., 2011; Rafique et al., 2011). These studies suggested that $\mathrm{N}_{2} \mathrm{O}$ fluxes were found to increase exponentially with increasing $\mathrm{N}$ rate for both grassland and cropland when multiple $\mathrm{N}$ rates were used. $\mathrm{N}_{2} \mathrm{O}$ emissions changed slightly when fertilizer $\mathrm{N}$ inputs were below a certain level, but increased 
rapidly above that level, or high rates of $\mathrm{N}$ fertilization led to increasing rates of $\mathrm{N}_{2} \mathrm{O}$ loss without economic gains in yield. For example, in a study of cropland, $\mathrm{N}_{2} \mathrm{O}$ fluxes were moderately low (ca. $20 \mathrm{~g} \mathrm{~N}_{2} \mathrm{O}-\mathrm{N} \mathrm{ha}^{-1}$ day $^{-1}$ ) at levels of $\mathrm{N}$ rates up to $101 \mathrm{~kg} \mathrm{~N}$ ha $^{-1}$, where grain yields were maximized, after which fluxes more than doubled (to $>50 \mathrm{~g} \mathrm{~N}_{2} \mathrm{O}-\mathrm{N} \mathrm{ha}^{-1}$ day $^{-1}$ ) (McSwiney et al., 2005). Similarly, in another study with multiple sites and $\mathrm{N}$ rates, the two $\mathrm{N}$ fertilizer rates above those recommended for maximum economic return $\left(135 \mathrm{~kg} \mathrm{~N} \mathrm{ha}^{-1}\right)$, average $\mathrm{N}_{2} \mathrm{O}$ fluxes were $43 \%$ $\left(18 \mathrm{~g} \mathrm{~N}_{2} \mathrm{O}-\mathrm{N} \mathrm{ha}^{-1}\right.$ day $\left.^{-1}\right)$ and $115 \%\left(26 \mathrm{~g} \mathrm{~N}_{2} \mathrm{O}-\mathrm{N} \mathrm{ha}^{-1}\right.$ day $\left.^{-1}\right)$ higher than were fluxes at the recommended rate, respectively, but the corn grain yield only increased by $2 \%$ and $6 \%$, respectively (Hoben et al., 2011). Although these examples were for cropland, the responses of $\mathrm{N}_{2} \mathrm{O}$ emission to $\mathrm{N}$ rates for grassland are most likely similar. Overall, the above examples highlight the potential to lower agricultural $\mathrm{N}_{2} \mathrm{O}$ fluxes with no or little yield penalty by reducing $\mathrm{N}$ fertilizer inputs to levels that just satisfy crop needs.

\subsection{Manure management}

Globally, manure production and use contribute more $\mathrm{N}_{2} \mathrm{O}$ to the atmosphere than synthetic fertilizer N (Davidson, 2009). The input of synthetic fertilizers on farms can be minimized, in part, by manure recycle within the farm (Fig. 1), i.e., by keeping a lower farm-scale $\mathrm{N}$ balance (or farm-gate N surplus), the difference between whole farm N inputs and outputs (Schröder et al., 2003). In general, a lower farm-gate surplus will result in lower losses of $\mathrm{N}_{2} \mathrm{O}$ from a farm. For example, Schils et al. (2006) reported that a decrease in surplus $\mathrm{N}$ of $1 \mathrm{~g} \mathrm{~kg}^{-1}$ milk lowered GHG emissions by approximately $29 \mathrm{~g} \mathrm{CO}_{2}$-eq $\mathrm{kg}^{-1}$ milk. Similarly, Olesen et al. (2006) reported that GHG 
emissions were found to decrease linearly with increasing farm $\mathrm{N}$ efficiency $\left(-16.5 \mathrm{~kg} \mathrm{CO}_{2}-\mathrm{eq} \mathrm{MJ}^{-1}\right.$ per $\%$ increase in efficiency).

$\mathrm{N}_{2} \mathrm{O}$ and other greenhouse gases can be produced and emitted at each stage of the 'manure management continuum', i.e., the livestock building, manure storage, manure treatment and manure spreading to land (Chadwick et al., 2011). Although all $\mathrm{N}$ losses represent potential $\mathrm{N}_{2} \mathrm{O}$ emissions, we will focus on direct $\mathrm{N}_{2} \mathrm{O}$ emission from the 'manure management continuum'. Other $\mathrm{N}$ losses and GHG emission related to manure management are referred to some comprehensive reviews (Rotz, 2004; Webb et al., 2010; Chadwick et al., 2011; Novak et al., 2011).

\subsection{1. $\mathrm{N}_{2} \mathrm{O}$ emissions during manure collection stage}

Manure is normally collected from animal houses and standing yards. Few studies have been conducted to measure $\mathrm{N}_{2} \mathrm{O}$ emissions from hard standing areas. The limited evidence shows very low or no $\mathrm{N}_{2} \mathrm{O}$ emissions at these areas due to predominantly anaerobic conditions (Ellis et al., 2001; Misselbrook et al., 2001).

$\mathrm{N}_{2} \mathrm{O}$ emissions from animal houses depend on whether bedding materials are used. The slurry/faeces/urine remains in a predominantly anaerobic state with little opportunity for the $\mathrm{NH}_{4}{ }^{+}$ to be nitrified, therefore little or no $\mathrm{N}_{2} \mathrm{O}$ emissions are likely to occur from such systems (Zhang et al., 2005). By comparing $\mathrm{N}_{2} \mathrm{O}$ and $\mathrm{NH}_{3}$ emissions from cattle and pigs housed in slurry-based and straw bedded buildings, Thorman et al. (2003) reported that there were little or no $\mathrm{N}_{2} \mathrm{O}$ emissions from slurry-based cattle or pig buildings, whist there were $\mathrm{N}_{2} \mathrm{O}$ emissions from cattle housed with straw bedding (4-5 $\mathrm{mg} \mathrm{N} \mathrm{m}^{-2} \mathrm{~d}^{-1}$ ). Much higher emissions may occur from deep litter systems, especially mechanical mixing of deep litter is involved (Groenestein et al., 1996). However, uncertainties remain. For example, Amon et al. (2001) reported there was no significant difference 
between slurry-based and straw-based stall systems for dairy cows in $\mathrm{N}_{2} \mathrm{O}$ emissions.

\subsection{2 $\mathrm{N}_{2} \mathrm{O}$ emissions during manure storage}

There is evidence showing that $\mathrm{N}_{2} \mathrm{O}$ and other $\mathrm{GHG}$ emissions during manure storage stage are greater than emissions after manure application (Amon et al., 2006; Clemens et al., 2006). Manure can either be stored as slurry (liquid) in lagoons or aboveground tanks or stored as solid manure in heaps, but manure is normally stored as slurry for intensive systems. For example, in Europe, livestock slurry is stored in 20-40 m diameter storage tanks with or without coverage, or in lagoons; in the United States and Canada, slurry is handled in stores or alternatively the slurry is diluted with water to encourage decomposition of the solids and pumped into anaerobic lagoons (Petersen et al., 2006). $\mathrm{N}_{2} \mathrm{O}$ emission from slurry/liquid manure is normally lower than from solid manure during storage (Sommer et al., 2000; Berg et al., 2006; IPCC, 2006). For example, the IPCC default emission factors for slurry/liquid manure and solid manure are $0.1 \%$ and $2 \%$, respectively (IPCC, 2006). However, the potential for methane emission from liquid manure is larger than from solid manure. For example, the emission factors proposed in the IPCC methodology for conversion of digestible organic carbon to methane are $1-2 \%$ for solid storage, $39-72 \%$ for slurry storage or extended pit storage, and up to $100 \%$ for manure stored in anaerobic lagoons (IPCC, 2000).

\subsubsection{Slurry storage and treatment}

$\mathrm{N}_{2} \mathrm{O}$ emission from slurry stored without surface cover is very low due to limited transformation of ammonium to nitrate under anaerobic conditions so that the subsequent denitrification is also very low. Stored slurry with a surface layer of straw or natural crust may be a 
source of $\mathrm{N}_{2} \mathrm{O}$ emissions (Sommer et al., 2000; Berg et al., 2006; VanderZaag et al., 2009). This is because the presence of a surface crust can provide aerobic conditions in the crust and hence nitrification can occur with $\mathrm{N}_{2} \mathrm{O}$ generation (Sommer et al., 2000). Manipulating (via addition of inorganic or organic acid) the balance between ammonia and ammonium by lowering the $\mathrm{pH}$ value of slurry below 6.0 is an effective measure to reduce emissions of $\mathrm{N}_{2} \mathrm{O}$ and $\mathrm{CH}_{4}$ and $\mathrm{NH}_{3}$ as well (Berg et al., 2006).

Several slurry treatment options, including slurry dilution, slurry additives, slurry aeration, slurry separation and anaerobic digestion are usually used to reduce slurry dry matter concentration in order to insure evenly distribution of nutrient after application (Amon et al., 2006). Although $\mathrm{NH}_{3}$ emissions may be lowered from the treated slurry, their efficiency in decreasing $\mathrm{N}_{2} \mathrm{O}$ emission has not been well investigated. Amon et al. (2006) compared $\mathrm{N}_{2} \mathrm{O}$ emissions from slurry which was treated with different methods (Table 1). $\mathrm{N}_{2} \mathrm{O}$ emissions were increased by separation, digestion, straw cover and aeration (Table 1). Fangueiro et al. (2008) studied $\mathrm{N}_{2} \mathrm{O}$ emission from five cattle slurry fractions with distinct characteristics obtained using a combined separation process (screw press + chemically enhanced settling using polyacrylamide (PAM)). In contrast, significant $\mathrm{N}_{2} \mathrm{O}$ emissions were observed only in the untreated slurry and liquid fractions of the separated slurry. Separation of slurry produces a solid fraction that is stored in manure heaps before being used as a fertilizer in crop production (Hansen et al., 2006).

Biogas treatment of animal manures is an upcoming technology because it is a way of producing renewable energy (biogas). However, little is known about effects of this management strategy on GHG emissions during fermentation (anaerobic digestion), storage, and field application of the substrates compared to untreated slurries (Clemens et al., 2006). The results are not consistent in terms of whether anaerobic digestion can reduce $\mathrm{N}_{2} \mathrm{O}$ emission during slurry storage or 
application. In a study, $\mathrm{N}_{2} \mathrm{O}$ emission from storage of anaerobically digested slurry was lower in winter but higher in summer relative to untreated slurry; and there was no difference between slurry types after application in their $\mathrm{N}_{2} \mathrm{O}$ emissions (Clemens et al., 2006). Another study reported higher $\mathrm{N}_{2} \mathrm{O}$ emission from anaerobically digested slurry (Amon et al., 2006).

Biological aerobic treatment is widely and is regarded as a necessary way to remove $\mathrm{N}$ from the slurry as $\mathrm{N}_{2}$ in order to protect water courses (Beline et al., 1999). The treatment results in a concentrated sludge (15\% of original volume) suitable for land spreading and an effluent ( $85 \%$ of original volume) that can be used as irrigation or discharged to the sewer system (Willers et al., 1996; Loyon et al., 2007). In addition to $\mathrm{N}_{2}$, higher emission rates of $\mathrm{N}_{2} \mathrm{O}$ (up to $13 \%$ ) and $\mathrm{NH}_{3}$ (up to $40 \%$ of total $\mathrm{N}$ ) may also be emitted from aerobically treated slurry dependent on the aeration rate and temperature (Willers et al., 1996; Beline et al., 1999). In contrast, Loyon et al. (2007) reported that aerobic treatment (using an intermittent aeration) decreased $\mathrm{NH}_{3}$ emission by $30-68 \%$ and $\mathrm{N}_{2} \mathrm{O}$ emission by $55 \%$ relative to untreated manure.

\subsubsection{Solid manure storage and treatment}

Solid manure heaps may be significant sources of $\mathrm{N}_{2} \mathrm{O}$ emissions (Chadwick et al., 1999). Maintaining anaerobic manure conditions can significantly reduce $\mathrm{N}_{2} \mathrm{O}$ emissions from solid manure storage heaps (Chadwick et al., 2011). For example, emissions of $\mathrm{NH}_{3}, \mathrm{~N}_{2} \mathrm{O}$, and $\mathrm{CH}_{4}$ were reduced by $12 \%, 99 \%$, and $88 \%$, respectively, when the manure heap was covered with an airtight material relative to the uncovered heap (Hansen et al., 2006). $\mathrm{N}_{2} \mathrm{O}$ losses were lower from the composted farmyard manure than from the anaerobically stacked manure (Amon et al., 2001). Compaction of manure in storage may also reduce $\mathrm{N}_{2} \mathrm{O}$ emissions by creating anaerobic conditions thus inhibiting nitrification. The inhibition of nitrification will prevent the formation of $\mathrm{NO}_{3}{ }^{-}$and 
hence there will be no losses of $\mathrm{N}_{2} \mathrm{O}$ via denitrification (Chadwick, 2005). Chadwick (2005) observed that compaction and covering also significantly reduced $\mathrm{N}_{2} \mathrm{O}$ emissions from cattle manure by ca. $30 \%$. However, the compaction may increase the potential for $\mathrm{CH}_{4}$ emissions (Chadwick, 2005).

Straw is often used as additive during solid manure storage. The effect of straw addition in lowering $\mathrm{N}_{2} \mathrm{O}$ emissions is not consistent (Brown et al., 2000; Sommer et al., 2000; Yamulki, 2006). Yamulki (2006) showed that straw addition to farm yard manure reduced the mean cumulative $\mathrm{N}_{2} \mathrm{O}$ emission by ca. $40 \%$ relative to conventional manure heaps with the emissions of $\mathrm{N}_{2} \mathrm{O}$ accounting for up to $0.3 \%$ and $0.7 \%$ of the total initial $\mathrm{N}$ in the straw-used and conventional heaps, respectively. In addition, straw addition reduced $\mathrm{CH}_{4}$ emissions (Yamulki, 2006). In contrast, $\mathrm{N}_{2} \mathrm{O}$ emissions increased by 2 times from solid dairy manure amended with chopped straw to water contents of 70 , 75 , and $80 \%$ relative to the unamended samples (Brown et al., 2000).

\subsubsection{Manure application}

$\mathrm{N}_{2} \mathrm{O}$ emissions following manure application to grassland have been reported by many studies (Chadwick et al., 2000; Velthof et al., 2003; Fangueiro et al., 2008; van der Meer, 2008; Luo et al., 2010; Chadwick et al., 2011). These studies indicated that $\mathrm{N}_{2} \mathrm{O}$ emissions from manure application may also be affected by manure type, timing, rates or placements of application. The efficiency of timing and rates in mitigating $\mathrm{N}_{2} \mathrm{O}$ emissions following manure application should be similar to fertilizer $\mathrm{N}$ application.

The effects of manure type on $\mathrm{N}_{2} \mathrm{O}$ emissions are not consistent and dependent on soil conditions, $\mathrm{N}$ and $\mathrm{C}$ content in manure, and application period (Chadwick et al., 2011). Clemens et al. (2006) reported that there was no difference between slurry types after application in their $\mathrm{N}_{2} \mathrm{O}$ 
emissions. Chadwick et al. (2000) compared $\mathrm{N}_{2} \mathrm{O}$ emissions following application of pig slurry and dairy cow slurry at equal volume in April, July and October. They found that cumulative $\mathrm{N}_{2} \mathrm{O}$ emissions were greater following application of dairy cow slurry than pig slurry in April, but significantly greater $\mathrm{N}_{2} \mathrm{O}$ emissions resulted from pig slurry-treated plots than dairy cow slurry-treated plots in July and October. These results indicate that manure type may not be regarded as a major factor affecting $\mathrm{N}_{2} \mathrm{O}$ emissions following manure application.

Solid manures can only be broadcast on the surface of grassland (Chadwick et al., 2011), but there are four main types of slurry application systems (Misselbrook et al., 2002), i.e., (a) surface broadcast - uniform covering of slurry across the crop; (b) band spreading - slurry placed in discrete bands on the crop by trailing hoses; (c) trailing shoe - slurry placed in discrete bands on the soil surface below the crop canopy; (d) injection - slurry placed in shallow, open slots or deep, closed slots within the soil. These manure application techniques were originally developed to reduce $\mathrm{N}$ losses via $\mathrm{NH}_{3}$ (Webb et al., 2010). Their efficiency in reducing emissions of $\mathrm{N}_{2} \mathrm{O}$ and other GHG emissions have not been well studied. According to a recent review (Webb et al., 2010), reduced- $\mathrm{NH}_{3}$ application techniques may increase emissions of $\mathrm{N}_{2} \mathrm{O}$, while placement of effluent below the soil surface by injection or aeration resulted in elevated $\mathrm{CH}_{4}$ emissions (Sistani et al., 2010). Therefore, the direct and indirect emissions of $\mathrm{N}_{2} \mathrm{O}$ and other GHG should be assessed. In addition, the results are not consistent even in the same study. For example, Sistani et al. (2010) compared $\mathrm{N}_{2} \mathrm{O}$ and other $\mathrm{GHG}$ emissions from a control, an inorganic fertilizer treatment receiving $179 \mathrm{~kg} \mathrm{~N} \mathrm{ha}{ }^{-1}$ as urea- $\mathrm{NH}_{4} \mathrm{NO}_{3}$ (UAN), and three swine effluent application methods (surface application, direct injection, and application in combination with soil aeration) that received a target rate of $200 \mathrm{~kg} \mathrm{~N} \mathrm{ha}^{-1}$ in two consecutive years. In year one, $\mathrm{N}_{2} \mathrm{O}$ emissions were similar for the UAN, surface effluent, and aeration effluent treatments (with an average of $0.72 \mathrm{~g} \mathrm{~N}_{2} \mathrm{O} \mathrm{m}^{-2}$ ) but 
higher than the injection treatment $\left(0.47 \mathrm{~g} \mathrm{~N}_{2} \mathrm{O} \mathrm{m}{ }^{-2}\right)$. However the pattern was reversed in year two, with the injection treatment emitting $0.82 \mathrm{~g} \mathrm{~N}_{2} \mathrm{O} \mathrm{m}{ }^{-2}$ and the remaining $\mathrm{N}$ source treatments emitting an average of $0.36 \mathrm{~g} \mathrm{~N}_{2} \mathrm{O} \mathrm{m}{ }^{-2}$. These results demonstrate that climatic conditions and application method need consideration when evaluating the impact of liquid manure management on GHG emissions (Sistani et al., 2010).

\subsection{Use of nitrification inhibitors to lower $\mathrm{N}_{2} \mathrm{O}$ emission from urine patch, application of synthetic fertilizer or manure}

Nitrification inhibitors (NIs) are compounds that delay the bacterial oxidation of ammonium to nitrite by depressing the activity of Nitrosomonas bacteria in the soil (Macadam et al., 2003; Watson et al., 2009). The most extensively studied NIs are dicyandiamide (DCD), 3,4-dimethyl pyrazole phosphate (DMPP) and nitrapyrin (Watson et al., 2009). As nitrate is the substrate for denitrification, the use of NIs along with ammonium based fertilizers, have the potential to reduce $\mathrm{N}_{2} \mathrm{O}$ emissions from both nitrification and denitrification.

A series of studies have shown that both $\mathrm{N}_{2} \mathrm{O}$ emissions and $\mathrm{NO}_{3}{ }^{-}$leaching from urine patches and application of fertilizer or manure can be significantly mitigated by treating grazed pasture soil with NIs including DCD and DMPP (Di et al., 2008; Qiu et al., 2010; de Klein et al., 2011; Di et al., 2012). In a study covering four different soils under different climatic and management conditions, $\mathrm{N}_{2} \mathrm{O}$ emissions from urine patches were declined by $61-73 \%$ with an average of $70 \%$ (Di et al., 2007). Recent studies in Ireland have shown that DCD can reduce $\mathrm{N}_{2} \mathrm{O}$ emissions by between 49 to 70\% from urine patches (Dennis et al., 2008; Selbie et al., 2010) and from slurry applied to grassland soils (Cahalan et al., 2010). In addition, DCD could reduce $\mathrm{NO}_{3}{ }^{-}$leaching from urine 
patches by $68-76 \%$ (Di et al., 2004; Di et al., 2005). Dennis et al. (2010) reported that nitrate leaching from urine patches was reduced by up to $45 \%$ through the use of DCD on free draining soils in Ireland. In New Zealand, Monaghan et al. (2009) showed that application of granular DCD lowered $\mathrm{NO}_{3}{ }^{-}$leaching by 21 to $56 \%$ from hydrologically isolated dairy pastures over a 4-year study. Ledgard et al. (2008) tested a novel approach to supplement animals with the NIs during the main $\mathrm{N}$ loss period in such a way that the NIs would be excreted by the animals, principally in the urine. Their study highlights the potential for using direct administration of $\mathrm{N}$ process inhibitors to grazing animals to reduce environmental $\mathrm{N}$ emissions from urine patches in pasture systems. However, despite the high recovery of DCD in urine (>85\%), there is a potential of metabolic residues of the inhibitors in the animals. It is still not clear whether the metabolic residues in animal products are detrimental to human health.

Akiyama et al. (2010) evaluated the effectiveness of NIs on $\mathrm{N}_{2} \mathrm{O}$ emissions using meta-analysis, and found that (i) NIs significantly reduced $\mathrm{N}_{2} \mathrm{O}$ emissions (mean: $-38 \%, 95 \%$ confidence interval: $-44 \%$ to $-31 \%$ ) compared with those of conventional fertilizers and their effectiveness was relatively consistent across the various types of inhibitors and land uses; (ii) NIs were effective in reducing $\mathrm{N}_{2} \mathrm{O}$ emission from both synthetic fertilizer $\mathrm{N}$ and organic fertilizers; and (iii) the efficacy was higher for grassland $(-54 \%,-60 \%$ to $-43 \%)$ than for upland fields $(-34 \%,-43 \%$ to $-26 \%)$ and paddy fields $(-30 \%,-39 \%$ to $-18 \%)$. In 2008 , DCD was reported to have decreased New Zealand's $\mathrm{N}_{2} \mathrm{O}$ emissions by $40.8 \mathrm{Gg} \mathrm{CO}_{2}$-eq, a $0.1 \%$ decrease in total agricultural $\mathrm{N}_{2} \mathrm{O}$ emissions (Anon, 2010). Due to the effectiveness of NIs in the decrease of both direct and indirect $\mathrm{N}_{2} \mathrm{O}$ emissions in New Zealand, they were considered an effective measure to lower $\mathrm{N}_{2} \mathrm{O}$ emissions from agricultural soils by the IPCC Fourth Assessment Report (IPCC, 2007).

Despite the effectiveness in lowering $\mathrm{N}_{2} \mathrm{O}$ emissions, some side effects have been reported for 
NIs. Use of NIs extended retention of $\mathrm{N}$ in the $\mathrm{NH}_{4}{ }^{+}$form in the soils, and hence they have the potential to increase $\mathrm{NH}_{3}$ volatilization, despite some studies reported DCD reduced $\mathrm{NH}_{3}$ volatilization by 28-38\% from urine patches (Zaman et al., 2012) A meta-analysis reveals that there is significance increase in $\mathrm{NH}_{3}$ loss (by $0.3-25.0 \%$ ) in both pasture and cropping soils after NIs application, especially for the soils with higher $\mathrm{pH}$ and lower cation exchange capacity (Kim et al., 2012).

There are some additional costs associated with using NIs. Subbarao et al. (2006) estimated that using nitrapyrin or DCD added about 25 to $30 \%$ to the cost of fertilizer N. Hence, Monaghan et al. (2009) suggested that in the absence of substantial herbage yield benefits, the cost of using inhibitors such as DCD was not economical unless farmers received carbon credit payments for the reduction in $\mathrm{N}_{2} \mathrm{O}$ emissions. Under current circumstances the cost of NIs is the main factor limiting their widespread use (Subbarao et al., 2006). For NIs to be more widely adopted, they will need to be competitively priced.

\subsection{Use of biological $\mathrm{N}$ fixation in association with forage legumes as an alternative to $\mathrm{N}$}

\section{fertilizer}

\subsubsection{N supply by biological $\mathrm{N}$ fixation}

Biological $\mathrm{N}$ fixation (BNF) in association with forage legumes provides an alternative $\mathrm{N}$ source for grasslands. White clover is the main legume in pastures and meadows of temperate regions and is adapted to survive in a range of grassland environments, while other legumes are of less importance (Rochon et al., 2004). Most often, white clover is grown with companion grasses. 
In pasture-based farming systems in Australia and New Zealand, $\mathrm{N}_{2}$ fixation by white clover was the main source of $\mathrm{N}$ input (Ledgard et al., 2001). Average biological $\mathrm{N}_{2}$ fixation in grazed permanent clover/grass pastures in temperate regions of the world has been reported to be 80 to 100 $\mathrm{kg} \mathrm{N} \mathrm{ha}^{-1} \mathrm{yr}^{-1}$ (range 10 to $270 \mathrm{~kg} \mathrm{~N} \mathrm{ha}^{-1} \mathrm{yr}^{-1}$ ) (Davies et al., 1996; Ledgard, 2001). This fixed $\mathrm{N}$ becomes available slowly over time to the grass in pastures after it is released into soil via exudates from living legume roots, by mineralization of senesced legume tissues and in excreta after consumption by grazing animals (Ledgard et al., 2009).

Rising costs of fertilizer $\mathrm{N}$ and environmental regulations governing stocking densities and fertilizer $\mathrm{N}$ use on farms is increasing interest in the use of white clover in grassland. In a recent review, Andrews et al. (2007) concluded that herbage and milk production from white clover-based pastures (perennial ryegrass with $20 \%$ white clover in herbage DM on an annual basis) are likely to be similar to that from a perennial ryegrass pasture receiving annual input of $200 \mathrm{~kg} \mathrm{ha}^{-1}$ of fertilizer $\mathrm{N}$ and around $70 \%$ of that obtained with perennial ryegrass receiving annual input of 350 to $400 \mathrm{~kg} \mathrm{ha}^{-1}$ of fertilizer N. In many countries in the northwest of Europe, these very high rates of fertilizer N input are no longer permissible due to regulations associated with the Nitrates Directive (European-Council, 1991). For example, in Ireland under Statutory Instruments (SI) No. 101 (Anon, 2009) the stocking density on dairy farms is limited to 2 dairy cows per hectare and, under these circumstances fertilizer $\mathrm{N}$ input should not exceed approximately $200 \mathrm{~kg} \mathrm{ha}^{-1}$. Subject to certain conditions farmers can seek derogation from these limits up to a maximum permissible fertilizer $\mathrm{N}$ input of approximately $279 \mathrm{~kg} \mathrm{ha}^{-1}$ (Anon, 2009). Similar or lower maximum allowable rates pertain in Northern Ireland, the Netherlands, Denmark and Germany (Humphreys, 2008).

\subsection{2 $\mathrm{N}_{2} \mathrm{O}$ emissions from legume based grasslands}


Although some early studies show that several Rhizobium species, in the free-living form, in legume root nodules or as isolated bacteroids can denitrify nitrate and release $\mathrm{N}_{2} \mathrm{O}$ (Rochette et al., 2005), recent studies suggest that direct $\mathrm{N}_{2} \mathrm{O}$ emission from BNF per se is negligible (Rochette et al., 2005; Carter et al., 2006; Zhong et al., 2009). The $\mathrm{N}_{2} \mathrm{O}$ emissions induced by the growth of legume crops/forages may be estimated solely as a function of the above-ground and below-ground $\mathrm{N}$ inputs from crop residues (Rochette et al., 2005; Carter et al., 2006; IPCC, 2006; Li et al., 2011). Accordingly $\mathrm{N}_{2} \mathrm{O}$ emissions from legume-based grasslands are much lower than fertilized grasslands. For example, Some study reported up to 5-fold of more $\mathrm{N}_{2} \mathrm{O}$ emission from heavily $\mathrm{N}$ fertilized grasslands than from their legume-based counterparts (Ruzjerez et al., 1994). A data synthesis indicates that the average soil $\mathrm{N}_{2} \mathrm{O}$ emissions from field-grown legumes, $\mathrm{N}$ fertilized grass pastures and crops, and unfertilized soils are 1.29, 3.22 and $1.20 \mathrm{~kg} \mathrm{~N} \mathrm{ha}^{-1} \mathrm{yr}^{-1}$, respectively (Jensen et al., 2012). Therefore $\mathrm{N}_{2} \mathrm{O}$ emissions from grass legume mixes are only slightly greater than background emissions (Rochette et al., 2005; Jensen et al., 2012). However soil $\mathrm{N}_{2} \mathrm{O}$ emissions for legume-based pastures grazed by animals will be significantly increased due to excreta patches. For eample, soil $\mathrm{N}_{2} \mathrm{O}$ emissions from white clover/ryegrass systems receiving no fertilizer $\mathrm{N}$ or $58 \mathrm{~kg}$ fertilizer-N ha ${ }^{-1} \mathrm{yr}^{-1}$ were found to be only $16-19 \%$ lower relative to a grass/fertilizer system (226 $\left.\mathrm{kg} \mathrm{N} \mathrm{ha}^{-1} \mathrm{yr}^{-1}\right)$ (Li et al., 2011).

Furthermore, $\mathrm{N}_{2} \mathrm{O}$ emissions may be indirectly lowered by legume-based systems. It allows dairy farmers to achieve the same net income at lower stocking densities compared with a higher stocked system reliant on high inputs of fertilizer $\mathrm{N}$ (Table 2). A lower stocking density means less $\mathrm{N}$ cycling within the system and lower urine deposition, which is a major source of $\mathrm{N}_{2} \mathrm{O}$ emission as aforementioned. Although limited studies have conducted to compare nitrate leaching or $\mathrm{NH}_{3}$ 
volatilization in legume and fertilizer-based systems, the current evidence suggests that $\mathrm{N}$ losses via these two pathways may be lowered in legume-based systems (Crews et al., 2004). Therefore indirect $\mathrm{N}_{2} \mathrm{O}$ emission from these $\mathrm{N}$ losses can be reduced. A study shows that nitrate leaching was reduced by $48 \%$ to $76 \%$ when fertilizer $\mathrm{N}$ was replaced by alfalfa (Medicago sativa) (Owens et al., 1994). Similarly, $\mathrm{NH}_{3}$ volatilization from legume residues was found to be much lower (Larsson et al., 1998).

Total GHG emissions have been reported to been substantially lowered by legume-based systems. An LCA analysis shows that GHG emissions from white clover-based dairy production systems (80-99 $\mathrm{kg} \mathrm{N} \mathrm{ha}^{-1} \mathrm{yr}^{-1}$ with stocking densities of $\left.1.8-2.2\right)$ are $11 \%$ to $23 \%$ lower than fertilizer-based systems (180-353 $\mathrm{kg} \mathrm{N} \mathrm{ha}^{-1} \mathrm{yr}^{-1}$ with stocking densities of 2.0-2.5) in Ireland (Yan et al., 2013) Similarly, GHG emissions per kg of milk from a grass/fertilizer system (160 $\left.\mathrm{kg} \mathrm{N} \mathrm{ha}^{-1}\right)$ were found to be $12 \%$ higher than from a clover/ryegrass system receiving no fertilizer $\mathrm{N}$ in New Zealand (Ledgard et al., 2009). Schils et al. (2005) used a farm level approach to compare GHG emissions from grass/fertilizer and grass/clover farms. Compared to a grass/fertilizer-N system, the GHG emissions (excluding carbon sequestration) from a grass/clover farm were $23 \%$ lower per ha and $11 \%$ lower per $\mathrm{kg}$ milk.

There is substantial economic benefit to replacing synthetic fertilizer $\mathrm{N}$ by BFN in grasslands (Rochon et al., 2004; Andrews et al., 2007; Humphreys et al., 2012). It is likely that fertilizer N costs will continue to increase relative to farm gate product prices (Humphreys et al., 2012). Under these circumstances the economics of using white clover become increasingly favourable, offering substantial potential to lower GHG emissions, if its use were to become widespread on farms.

\subsection{Combined options to mitigate $\mathrm{N}_{2} \mathrm{O}$ emission}


Efficiencies of each option in lowering $\mathrm{N}_{2} \mathrm{O}$ emissions are presented in Table 3. At each stage of farm $\mathrm{N}$ flow, there are options to lower $\mathrm{N}_{2} \mathrm{O}$ emissions. Although single option of $\mathrm{N}$ management has the potential to lower $\mathrm{N}_{2} \mathrm{O}$ emission, the mitigation capacity is relatively small. In some cases, the decrease of $\mathrm{N}_{2} \mathrm{O}$ emission in one step of the $\mathrm{N}$ flow (Figure 1) may be offset by increased $\mathrm{N}_{2} \mathrm{O}$ losses in another step. For example, restricted grazing by keeping animals off grazing paddocks and on stand-off/feed pads or in animal houses can efficiently lower $\mathrm{N}_{2} \mathrm{O}$ emission from the grazing paddocks due to excreta deposition. However, this decrease may be offset if manure is not effectively managed during in-house or storage stage. In other words, effective measures should be taken at each step during $\mathrm{N}$ flow or combined options should be used in order to mitigate $\mathrm{N}_{2} \mathrm{O}$ emission at the farm level.

So far few studies have been conducted to investigate the effectiveness of combined options in lowering $\mathrm{N}_{2} \mathrm{O}$ emission. Nevertheless, according to the limited available evidence, the effectiveness of the combined options to mitigate $\mathrm{N}_{2} \mathrm{O}$ emission may not be simply additive of individual options. For example, $\mathrm{N}_{2} \mathrm{O}$ emission was lowered by 39,41 and $55 \%$ from restricted grazing, DCD application and their combination in a pasture of New Zealand (Luo et al., 2010). Quantitative analysis of $\mathrm{N}$ flows and $\mathrm{N}_{2} \mathrm{O}$ losses in dairy farming systems reveal that the implementation of a package of measures to improve $\mathrm{N}$ management may reduce $\mathrm{N}_{2} \mathrm{O}$ emissions from dairy farming systems by up to $70 \%$ (Velthof et al., 1997). Vallejo et al. (2005) showed that addition of dicyandiamide reduced $\mathrm{N}_{2} \mathrm{O}$ emissions from $2.95 \%$ to $0.50 \%$ of applied $\mathrm{N}$ when injected into soil in a Mediterranean climate. The above studies show that the combined options were more effective in mitigating $\mathrm{N}_{2} \mathrm{O}$ emission than individual option but the decrease in $\mathrm{N}_{2} \mathrm{O}$ emission by the combined options was lower than the total decrease of $\mathrm{N}_{2} \mathrm{O}$ emission by the individual options. More studies are undoubtedly needed to investigate the effectiveness of combined options in 
mitigate $\mathrm{N}_{2} \mathrm{O}$ emission.

\section{Conclusions}

The efficiencies of major $\mathrm{N}$ management options in mitigating $\mathrm{N}_{2} \mathrm{O}$ emissions from grassland-based agriculture are reviewed:

(1) Restricted grazing by reducing grazing time is an effective way to decrease $\mathrm{N}_{2} \mathrm{O}$ emissions from excreta patches. Balancing the protein-to-energy ratios in the diets of ruminants can also decrease $\mathrm{N}_{2} \mathrm{O}$ emissions from excreta patches.

(2) Among the managements of synthetic fertilizer $\mathrm{N}$ application, only adjusting fertilizer $\mathrm{N}$ rate and use of slow-released fertilizers are proven to be effective in lowering $\mathrm{N}_{2} \mathrm{O}$ emissions form grasslands.

(3) Use of bedding materials may increase $\mathrm{N}_{2} \mathrm{O}$ emissions from animal houses. Manure storage as slurry, manipulating slurry $\mathrm{pH}$ to values lower than 6 and storage as solid manure under anaerobic conditions help to reduce $\mathrm{N}_{2} \mathrm{O}$ emissions during manure storage stage. For manure land application, $\mathrm{N}_{2} \mathrm{O}$ emissions can be mitigated after reducing manure $\mathrm{N}$ inputs to levels that just satisfy crop needs.

(4) Nitrification inhibitors have been shown to substantially lower $\mathrm{N}_{2} \mathrm{O}$ emissions associated with applications of fertilizers and manures and from urine deposited during grazing.

(5) $\mathrm{N}_{2} \mathrm{O}$ emissions from legume based grasslands are generally lower than fertilizer-based systems. In addition, legume-based systems can be as profitable as conventional fertilizer-N-based systems. 
Acknowledgements. This work was financially supported by the Irish Department of Agriculture, Fisheries and Food Research Stimulus Fund (RSF 07 516, RSF 07 511) under the National Development Plan 2007-2013.

\section{References}

Akiyama, H., Yan, X. and Yagi, K., 2010. Evaluation of effectiveness of enhanced-efficiency fertilizers as mitigation options for $\mathrm{N}_{2} \mathrm{O}$ and $\mathrm{NO}$ emissions from agricultural soils: meta-analysis. Global Change Biology 16, 1837-1846.

Amon, B., Amon, T., Boxberger, J. and Alt, C., 2001. Emissions of $\mathrm{NH}_{3}, \mathrm{~N}_{2} \mathrm{O}$ and $\mathrm{CH}_{4}$ from dairy cows housed in a farmyard manure tying stall (housing, manure storage, manure spreading). Nutrient Cycling in Agroecosystems 60, 103-113.

Amon, B., Kryvoruchko, V., Amon, T. and Zechmeister-Boltenstern, S., 2006. Methane, nitrous oxide and ammonia emissions during storage and after application of dairy cattle slurry and influence of slurry treatment. Agriculture Ecosystems \& Environment 112, 153-162.

Andrews, M., Scholefield, D., Abberton, M. T., McKenzie, B. A., Hodge, S. and Raven, J. A., 2007. Use of white clover as an alternative to nitrogen fertiliser for dairy pastures in nitrate vulnerable zones in the UK: productivity, environmental impact and economic considerations. Annals of Applied Biology 151, 11-23.

Anon, 2009. European Communities (Good Agricultural Practice for Protection of Waters) Regulations 2009. SI 101 of 2009. Dublin: Department of Environment, Heritage and Local 
Government, The Stationary Office.

Anon, 2010. New Zealand's Greenhouse Gas Inventory 1990-2008, Report submitted fulfilling the requirements under the United Nations Framework Convention on Climate Change and New Zealand's submission under Article 7.1 of the Kyoto Protocol Ministry for the Environment. In ed.^eds.), pp. 295. Wellington, New Zealand.

Beline, F., Martinez, J., Chadwick, D., Guiziou, F. and Coste, C. M., 1999. Factors affecting nitrogen transformations and related nitrous oxide emissions from aerobically treated piggery slurry. Journal of agricultural Engineering Research 73, 235-243.

Berg, W., Brunsch, R. and Pazsiczki, I., 2006. Greenhouse gas emissions from covered slurry compared with uncovered during storage. Agriculture, Ecosystems \& Environment 112, 129-134.

Bouwman, A. F., Boumans, L. J. M. and Batjes, N. H., 2002. Emissions of $\mathrm{N}_{2} \mathrm{O}$ and NO from fertilized fields: Summary of available measurement data. Global Biogeochemical Cycles 16, 1058, doi:1010.1029/2001GB001811.

Bremner, J. M., 1997. Sources of nitrous oxide in soils. Nutrient Cycling in Agroecosystems 49, 7-16.

Brown, H. A., Wagner-Riddle, C. and Thurtell, G. W., 2000. Nitrous oxide flux from solid dairy manure in storage as affected by water content and redox potential. Journal of Environmental Quality 29, 630-638.

Cahalan, E., Richards, K. G., Mueller, C., M.I., K., Laughlin, R., Watson, C., Hennessy, D. and Devaney, D., 2010. Can the nitrification inhibitor DCD decrease nitrous oxide emissions from slurry applied to grassland? In BSAS International Conference to address future challenges for land use ed.^eds.). Queen's University, Belfast, Northern Ireland. 
Carter, M. and Ambus, P., 2006. Biologically fixed $\mathrm{N}_{2}$ as a source for $\mathrm{N}_{2} \mathrm{O}$ production in a grass-clover mixture, measured by ${ }^{15} \mathrm{~N}_{2}$. Nutrient Cycling in Agroecosystems 74, 13-26.

Chadwick, D., Sommer, S. G., Thorman, R., Fangueiro, D., Cardenas, L., Amon, B. and Misselbrook, T., 2011. Manure management: Implications for greenhouse gas emissions. Animal Feed Science and Technology 166-67, 514-531.

Chadwick, D. R., 2005. Emissions of ammonia, nitrous oxide and methane from cattle manure heaps: effect of compaction and covering. Atmospheric Environment 39, 787-799.

Chadwick, D. R., Pain, B. F. and Brookman, S. K. E., 2000. Nitrous oxide and methane emissions following application of animal manures to grassland. Journal of Environmental Quality 29, 277-287.

Chadwick, D. R., Sneath, R. W., Phillips, V. R. and Pain, B. F., 1999. A UK inventory of nitrous oxide emissions from farmed livestock. Atmospheric Environment 33, 3345-3354.

Clemens, J., Trimborn, M., Weiland, P. and Amon, B., 2006. Mitigation of greenhouse gas emissions by anaerobic digestion of cattle slurry. Agriculture, Ecosystems \& Environment $112,171-177$.

Clough, T. J., Ray, J. L., Buckthought, L. E., Calder, J., Baird, D., O'Callaghan, M., Sherlock, R. R. and Condron, L. M., 2009. The mitigation potential of hippuric acid on $\mathrm{N}_{2} \mathrm{O}$ emissions from urine patches: An in situ determination of its effect. Soil Biology \& Biochemistry 41, 2222-2229.

Crews, T. E. and Peoples, M. B., 2004. Legume versus fertilizer sources of nitrogen: ecological tradeoffs and human needs. Agriculture, Ecosystems and Environment 102, 279-297.

Crews, T. E. and Peoples, M. B., 2005. Can the synchrony of nitrogen supply and crop demand be improved in legume and fertilizer-based agroecosystems? A review. Nutrient Cycling in 
Agroecosystems 72, 101-120.

Davidson, E. A., 2009. The contribution of manure and fertilizer nitrogen to atmospheric nitrous oxide since 1860. Nature Geoscience 2, 659-662.

Davidson, E. A., 2012. Representative concentration pathways and mitigation scenarios for nitrous oxide. Environmental Research Letters 7.

Davies, D. A. and Hopkins, A., 1996. Production benefits of legumes in grassland. In: D. Younie (eds.) Legumes in sustainable Farming Systems. Occasional Symposium No 30, pp. 234-246. UK: British Grassland Society.

de Klein, C. A. M., Cameron, K. C., Di, H. J., Rys, G., Monaghan, R. M. and Sherlock, R. R., 2011. Repeated annual use of the nitrification inhibitor dicyandiamide (DCD) does not alter its effectiveness in reducing $\mathrm{N} 2 \mathrm{O}$ emissions from cow urine. Animal Feed Science and Technology 166-67, 480-491.

de Klein, C. A. M. and Ledgard, S. F., 2005. Nitrous oxide emissions from New Zealand agriculture - key sources and mitigation strategies. Nutrient Cycling in Agroecosystems 72, 77-85.

de Klein, C. A. M., Pinares-Patino, C. and Waghorn, G. C., 2008. Greenhouse gas emissions. In: R. W. McDowell (eds.) Environmental Impacts of Pasture-based Farming, pp. 1-32. CAB International.

de Klein, C. A. M., Sherlock, R. R., Cameron, K. C. and Weerden, T. J. v. d., 2001. Nitrous oxide emissions from agricultural soils in New Zealand - a review of current knowledge and directions for future research. Journal of The Royal Society of New Zealand 31, 543-574.

de Klein, C. A. M., Smith, L. C. and Monaghan, R. M., 2006. Restricted autumn grazing to reduce nitrous oxide emissions from dairy pastures in Southland, New Zealand. Agriculture Ecosystems \& Environment 112, 192-199. 
deKlein, C. A. M. and Ledgard, S. F., 2005. Nitrous oxide emissions from New Zealand agriculture - key sources and mitigation strategies. Nutrient Cycling in Agroecosystems 72, 77-85.

Dennis, S., Cameron, K., H.Di, Moir, J. and Richards, K., 2010. Dicyandiamide (DCD) reduces nitrate losses from Irish soils. In Proceedings of the 19th World Congress of Soil Science; Soil Solutions for a Changing World. Symposium 4.1.2; Management and protection of receiving environments (R. Gilkes and N. Prakongkep, ed.^eds.), pp. 42-45. Brisbane, Australia.

Dennis, S. J., Richards, K. G., Cameron, K. C., Di, H. J., Moir, J. L., Fay, D., Staples, V. and Sills, P., 2008. Dicyandiamide (DCD) nitrification inhibitor reduces nitrous oxide emissions from soils. In Agricultural Research Forum Tullamore ed.^eds.). Ireland.

Di, H. J. and Cameron, K. C., 2004. Treating grazed pasture soil with a nitrification inhibitor, eco-n (TM), to decrease nitrate leaching in a deep sandy soil under spray irrigation - a lysimeter study. New Zealand Journal of Agricultural Research 47, 351-361.

Di, H. J. and Cameron, K. C., 2005. Reducing environmental impacts of agriculture by using a fine particle suspension nitrification inhibitor to decrease nitrate leaching from grazed pastures. Agriculture Ecosystems \& Environment 109, 202-212.

Di, H. J. and Cameron, K. C., 2008. Sources of nitrous oxide from N-15-labelled animal urine and urea fertiliser with and without a nitrification inhibitor, dicyandiamide (DCD). Australian Journal of Soil Research 46, 76-82.

Di, H. J. and Cameron, K. C., 2012. How does the application of different nitrification inhibitors affect nitrous oxide emissions and nitrate leaching from cow urine in grazed pastures? Soil Use and Management 28, 54-61.

Di, H. J., Cameron, K. C. and Sherlock, R. R., 2007. Comparison of the effectiveness of a 
nitrification inhibitor, dicyandiamide, in reducing nitrous oxide emissions in four different soils under different climatic and management conditions. Soil Use and Management 23, $1-9$.

Eckard, R. J., Grainger, C. and de Klein, C. A. M., 2010. Options for the abatement of methane and nitrous oxide from ruminant production: A review. Livestock Science 130, 47-56.

Ellis, S., Webb, J., Misselbrook, T. and Chadwick, D., 2001. Emission of ammonia (NH3), nitrous oxide (N2O) and methane (CH4) from a dairy hardstanding in the UK. Nutrient Cycling in Agroecosystems 60, 115-122.

European-Council, 1991. Directive 91/676/EEC concerning the protection of waters against pollution caused by nitrates from agricultural sources. Official Journal of the European Union L 375, 1-8.

Fangueiro, D., Senbayram, M., Trindade, H. and Chadwick, D., 2008. Cattle slurry treatment by screw press separation and chemically enhanced settling: Effect on greenhouse gas emissions after land spreading and grass yield. Bioresource Technology 99, 7132-7142.

FAO, 2009. FAO Statistical Yearbook. Available online at: http://www.fao.org/economic/ess/publications-studies/statistical-yearbook/fao-statistical-yea rbook-2009/a-resources/en/. In ed.^eds.).

Groenestein, C. M. and VanFaassen, H. G., 1996. Volatilization of ammonia, nitrous oxide and nitric oxide in deep-litter systems for fattening pigs. Journal of agricultural Engineering Research $65,269-274$.

Hall, A., 2005. Benefits of enhanced-efficiency fertilizer for the environment. In: (eds.) International Fertilizer Association International workshop on enhanced-efficiency fertilizers. Frankfurt, Germany: International Fertilzier Industry Association. 
Halvorson, A. D., Del Grosso, S. J. and Reule, C. A., 2008. Nitrogen, tillage, and crop rotation effects on nitrous oxide emissions from irrigated cropping systems. Journal of Environmental Quality 37, 1337-1344.

Hansen, M. N., Henriksen, K. and Sommer, S. G., 2006. Observations of production and emission of greenhouse gases and ammonia during storage of solids separated from pig slurry: Effects of covering. Atmospheric Environment 40, 4172-4181.

Hoben, J. P., Gehl, R. J., Millar, N., Grace, P. R. and Robertson, G. P., 2011. Nonlinear nitrous oxide (N2O) response to nitrogen fertilizer in on-farm corn crops of the US Midwest. Global Change Biology 17, 1140-1152.

Humphreys, J., 2008. Nutrient issues on Irish farms and solutions to lower losses. International Journal of Dairy Technology 61, 36-42.

Humphreys, J., Mihailescu, E. and Casey, I. A., 2012. An economic comparison of systems of dairy production based on $\mathrm{N}$-fertilized grass and grass-white clover grassland in a moist maritime environment. Grass and Forage Science 67, 519-525.

IPCC, 2000. IPCC Good Practice Guidance and Uncertainty Management in National Greenhouse Gas Inventories. Kanagawa, Japan, IGES (Institute for Global Environmental Strategies). IPCC, 2006. IPCC guidelines for national greenhouse gas inventories. Hayama, Japan, IGES. IPCC, 2007. Climate Change 2007: Mitigation. Contribution of Working Group III to the Fourth Assessment Report of the Intergovernmental Panel on Climate Change. Cambridge, United Kingdom and New York, NY, USA, Cambridge University Press.

Jensen, E. S., Peoples, M. B., Boddey, R. M., Gresshoff, P. M., Hauggaard-Nielsen, H., Alves, B. J. R. and Morrison, M. J., 2012. Legumes for mitigation of climate change and the provision of feedstock for biofuels and biorefineries. A review. Agronomy for Sustainable 
Development 32, 329-364.

Kebreab, E., France, J., Beever, D. E. and Castillo, A. R., 2001. Nitrogen pollution by dairy cows and its mitigation by dietary manipulation. Nutrient Cycling in Agroecosystems 60, $275-285$.

Kennedy, E., McEvoy, M., Murphy, J. and O'Donovan, M., 2009. Effect of restricted access time to pasture on dairy cow milk production, grazing behavior, and dry matter intake. Journal of Dairy Science 92, 168-176.

Kim, D.-G., Mishurov, M. and Kiely, G., 2010. Effect of increased N use and dry periods on N2O emission from a fertilized grassland. Nutrient Cycling in Agroecosystems 88, 397-410.

Kim, D.-G., Saggar, S. and Roudier, P., 2012. The effect of nitrification inhibitors on soil ammonia emissions in nitrogen managed soils: a meta-analysis. Nutrient Cycling in Agroecosystems 93, 51-64.

Kool, D. M., Hoffland, E., Hummelink, E. W. J. and van Groenigen, J. W., 2006. Increased hippuric acid content of urine can reduce soil N2O fluxes. Soil Biology and Biochemistry 38, 1021-1027.

Larsson, L., Ferm, M., Kasimir-Klemedtsson, A. and Klemedtsson, L., 1998. Ammonia and nitrous oxide emissions from grass and alfalfa mulches. Nutrient Cycling in Agroecosystems 51, 41-46.

Ledgard, S., Schils, R., Eriksen, J. and Luo, J., 2009. Environmental impacts of grazed clover/grass pastures. Irish Journal of Agricultural and Food Research 48, 209-226.

Ledgard, S. F., 2001. Nitrogen cycling in low input legume-based agriculture, with emphasis on legume/grass pastures. Plant and Soil 228, 43-59.

Ledgard, S. F., Menneer, J. C., Dexter, M. M., Kear, M. J., Lindsey, S., Peters, J. S. and Pacheco, D., 
2008. A novel concept to reduce nitrogen losses from grazed pastures by administering soil nitrogen process inhibitors to ruminant animals: A study with sheep. Agriculture, Ecosystems \& Environment 125, 148-158.

Ledgard, S. F., Sprosen, M. S., Penno, J. W. and Rajendram, G. S., 2001. Nitrogen fixation by white clover in pastures grazed by dairy cows: Temporal variation and effects of nitrogen fertilization. Plant and Soil 229, 177-187.

Ledgard, S. F., Welten, B., Menneer, J. C., Betteridge, K., Crush, J. R. and Barton, M. D., 2007. New nitrogen mitigation technologies for evaluation in the Lake Taupo catchment. Proceedings of the New Zealand Grassland Association 69, 117-121.

Li, D., Lanigan, G. and Humphreys, J., 2011. Measured and Simulated Nitrous Oxide Emissions from Ryegrass- and Ryegrass/White Clover-Based Grasslands in a Moist Temperate Climate. PLoS ONE 6, e26176.

Liu, X. J., Mosier, A. R., Halvorson, A. D. and Zhang, F. S., 2006. The impact of nitrogen placement and tillage on $\mathrm{NO}, \mathrm{N}_{2} \mathrm{O}, \mathrm{CH}_{4}$ and $\mathrm{CO}_{2}$ fluxes from a clay loam soil. Plant and Soil 280, 177-188.

Loyon, L., Guiziou, F., Beline, E. and Peu, P., 2007. Gaseous Emissions $\left(\mathrm{NH}_{3}, \mathrm{~N}_{2} \mathrm{O}, \mathrm{CH}_{4}\right.$ and $\left.\mathrm{CO}_{2}\right)$ from the aerobic treatment of piggery slurry - Comparison with a conventional storage system. Biosystems Engineering 97, 472-480.

Luo, J., de Klein, C. A. M., Ledgard, S. F. and Saggar, S., 2010. Management options to reduce nitrous oxide emissions from intensively grazed pastures: A review. Agriculture Ecosystems \& Environment 136, 282-291.

Luo, J., Ledgard, S. F., de Klein, C. A. M., Lindsey, S. B. and Kear, M., 2008a. Effects of dairy farming intensification on nitrous oxide emissions. Plant and Soil 309, 227-237. 
Luo, J., Ledgard, S. F. and Lindsey, S. B., 2008b. A test of a winter farm management option for mitigating nitrous oxide emissions from a dairy farm. Soil Use and Management 24, 121-130.

Macadam, X., Del-Prado, A., Merino, P., Estavillo, J., Pinto, M. and Gonzá-lez-Murua, C., 2003. Dicyandiamide and 3,4-dimethyl pyrazole phosphate decrease $\mathrm{N}_{2} \mathrm{O}$ emissions from grassland but dicyandiamide produces deleterious effects in clover. Journal of Plant Physiology 160, 1517-1523.

McSwiney, C. P. and Robertson, G. P., 2005. Nonlinear response of N2O flux to incremental fertilizer addition in a continuous maize (Zea mays L.) cropping system. Global Change Biology 11, 1712-1719.

Millar, N., Robertson, G. P., Grace, P. R., Gehl, R. J. and Hoben, J. P., 2010. Nitrogen fertilizer management for nitrous oxide (N2O) mitigation in intensive corn (Maize) production: an emissions reduction protocol for US Midwest agriculture. Mitigation and Adaptation Strategies for Global Change 15, 185-204.

Misselbrook, T. H., Powell, J. M., Broderick, G. A. and Grabber, J. H., 2005. Dietary manipulation in dairy cattle: Laboratory experiments to assess the influence on ammonia emissions. Journal of Dairy Science 88, 1765-1777.

Misselbrook, T. H., Smith, K. A., Johnson, R. A. and Pain, B. F., 2002. Slurry application techniques to reduce ammonia emissions: Results of some UK field-scale experiments. Biosystems Engineering 81, 313-321.

Misselbrook, T. H., Webb, J., Chadwick, D. R., Ellis, S. and Pain, B. F., 2001. Gaseous emissions from outdoor concrete yards used by livestock. Atmospheric Environment 35, 5331-5338.

Monaghan, R., Smith, L. and Ledgard, S., 2009. The effectiveness of a granular formulation of 
dicyandiamide (DCD) in limiting nitrate leaching from a grazed dairy pasture. New Zealand Journal of Agricultural Research 52, 145-159.

Nielsen, N. M., Kristensen, T., Norgaard, P. and Hansen, H., 2003. The effect of low protein supplementation to dairy cows grazing clover grass during half of the day. Livestock Production Science 81, 293-306.

Novak, S. M. and Fiorelli, J. L., 2011. Greenhouse Gases and Ammonia Emissions from Organic Mixed Crop-Dairy Systems: A Critical Review of Mitigation Options.

Oenema, O., Velthof, G. L., Yamulki, S. and Jarvis, S. C., 1997. Nitrous oxide emissions from grazed grassland. Soil Use and Management 13, 288-295.

Oenema, O., Wrage, N., Velthof, G. L., van Groenigen, J. W., Dolfing, J. and Kuikman, P. J., 2005. Trends in global nitrous oxide emissions from animal production systems. Nutrient Cycling in Agroecosystems 72, 51-65.

Olesen, J., Schelde, K., Weiske, A., Weisbjerg, M., Asman, W. and Djurhuus, J., 2006. Modelling greenhouse gas emissions from European conventional and organic dairy farms. Agriculture, Ecosystems and Environment 112, 207-220.

Owens, L. B., Edwards, W. M. and Vankeuren, R. W., 1994. Groundwater nitrate levels under fertilized grass and grass-legume pastures. Journal of Environmental Quality 23, 752-758.

Petersen, S. O. and Miller, D. N., 2006. Greenhouse gas mitigation by covers on livestock slurry tanks and lagoons? Journal of the Science of Food and Agriculture 86, 1407-1411.

Phillips, R. L., Tanaka, D. L., Archer, D. W. and Hanson, J. D., 2009. Fertilizer Application Timing Influences Greenhouse Gas Fluxes Over a Growing Season. Journal of Environmental Quality 38, 1569-1579.

Qiu, W., Di, H. J., Cameron, K. C. and Hu, C., 2010. Nitrous oxide emissions from animal urine as 
affected by season and a nitrification inhibitor dicyandiamide. Journal of Soils and Sediments 10, 1229-1235.

Rafique, R., Hennessy, D. and Kiely, G., 2011. Nitrous Oxide Emission from Grazed Grassland Under Different Management Systems. Ecosystems 14, 563-582.

Ravishankara, A. R., Daniel, J. S. and Portmann, R. W., 2009. Nitrous oxide $\left(\mathrm{N}_{2} \mathrm{O}\right)$ : the dominant ozone-depleting substance emitted in the 21st Century. Science 326, 123-125.

Reay, D. S., Davidson, E. A., Smith, K. A., Smith, P., Melillo, J. M., Dentener, F. and Crutzen, P. J., 2012. Global agriculture and nitrous oxide emissions. Nature Climate Change 2, 410-416.

Rochette, P. and Janzen, H. H., 2005. Towards a revised coefficient for estimating $\mathrm{N}_{2} \mathrm{O}$ emissions from legumes. Nutrient Cycling in Agroecosystems 73, 171-179.

Rochon, J. J., Doyle, C. J., Greef, J. M., Hopkins, A., Molle, G., Sitzia, M., Scholefield, D. and Smith, C. J., 2004. Grazing legumes in Europe: a review of their status, management, benefits, research needs and future prospects. Grass and Forage Science 59, 197-214.

Rotz, C. A., 2004. Management to reduce nitrogen losses in animal production. Journal of Animal Science 82, E119-E137.

Ruzjerez, B. E., White, R. E. and Ball, P. R., 1994. Long-term measurement of denitrification in three contrasting pastures grazed by sheep. Soil Biology \& Biochemistry 26, 29-39.

Schils, R. L. M., Eriksen, J., Ledgard, S. F., Vellinga, T. V., Kuikman, P. J., Luo, J., Petersen, S. O. and Velthof, G. L., 2011. Strategies to mitigate nitrous oxide emissions from herbivore production systems. animal FirstView, 1-12.

Schils, R. L. M., Verhagen, A., Aarts, H. F. M., Kuikman, P. J. and Šebek, L. B. J., 2006. Effect of improved nitrogen management on greenhouse gas emissions from intensive dairy systems in the Netherlands. Global Change Biology 12, 382-391. 
Schils, R. L. M., Verhagen, A., Aarts, H. F. M. and Šebek, L. B. J., 2005. A farm level approach to define successful mitigation strategies for GHG emissions from ruminant livestock systems. Nutrient Cycling in Agroecosystems 71, 163-175.

Schröder, J. J., Aarts, H. F. M., ten-Berge, H. F. M., van-Keulen, H. and Neeteson, J. J., 2003. An evaluation of whole-farm nitrogen balances and related indices for efficient nitrogen use. European Journal of Agronomy 20, 33-34.

Selbie, D., Lanigan, G., Di, H. J., Moir, J. L., Cameron, K. C. and Richards, K. G., 2010. Importance of urinary $\mathrm{N}$ content on nitrous oxide emissions from grassland soil lysimeters. In Ecotrons $\&$ Lysimeters Conference ed.^eds.). Nancy, France.

Sistani, K. R., Warren, J. G., Lovanh, N., Higgins, S. and Shearer, S., 2010. Greenhouse Gas Emissions from Swine Effluent Applied to Soil by Different Methods. Soil Science Society of America Journal 74, 429-435.

Smith, K. A., Mosier, A. R., Crutzen, P. J. and Winiwarter, W., 2012. The role of N2O derived from crop-based biofuels, and from agriculture in general, in Earth's climate. Philosophical Transactions of the Royal Society B-Biological Sciences 367, 1169-1174.

Smith, P., Martino, D., Cai, Z., Gwary, D., Janzen, H., Kumar, P., McCarl, B., Ogle, S., O'Mara, F., Rice, C., Scholes, B., Sirotenko, O., Howden, M., McAllister, T., Pan, G., Romanenkov, V., Schneider, U., Towprayoon, S., Wattenbach, M. and Smith, J., 2008. Greenhouse gas mitigation in agriculture. Philosophical Transactions of the Royal Society B-Biological Sciences 363, 789-813.

Smith, P., Martino, D., Cai, Z., Gwary, D., Janzen, H. H., Kumar, P., McCarl, B., Ogle, S., O'Mara, F., Rice, C., Scholes, R. J., Sirotenko, O., Howden, M., McAllister, T., Pan, G., Romanenkov, V., Schneider, U., Towprayoon, S., Wattenbach, M. and J.U. Smith, a. d. r., 2007. 
Greenhouse gas mitigation in agriculture. Philosophical Transactions of the Royal Society B $363,789-813$.

Solomon, S., Qin, D., Manning, M., Chen, Z., Marquis, M., Averyt, K. B., Tignor, M. and Miller, H. L., 2007. Climate Change 2007: The Physical Science Basis. Contribution of Working Group I to the Fourth Assessment Report of the Intergovernmental Panel on Climate Change. Cambridge University Press, Cambridge, United Kingdom and New York, NY, USA.

Sommer, S. G., Petersen, S. O. and Sogaard, H. T., 2000. Greenhouse gas emission from stored livestock slurry. Journal of Environmental Quality 29, 744-751.

Stehfest, E. and Bouwman, L., 2006. N2O and NO emission from agricultural fields and soils under natural vegetation: summarizing available measurement data and modeling of global annual emissions. Nutrient Cycling in Agroecosystems 74, 207-228.

Subbarao, G., Ito, O., Sahrawat, K., Berry, W., Nakahara, K., Ishikawa, T., Watanabe, T., Suenage, K., Rondon, M. and Rao, I., 2006. Scope and strategies for regulation of nitrification in agricultural systems. Critical Reviews in Plant Sciences 25, 303-335.

Thorman, R., Harrison, R., Cooke, S. D., Ellis, S., Chadwick, D. R., Burston, M. and Balsdon, S. L., 2003. Nitrous oxide emissions from slurry- and straw-based systems for cattle and pigs in relation to emissions of ammonia. In Proceedings of SAC/ SEPA Conference on Agriculture, Waste and the Environment (I. McTaggart and L. Gairns, ed.^eds.), pp. 26-32. Edinburgh, 26-28 March.

Vallejo, A., Garcia-Torres, L., Diez, J. A., Arce, A. and Lopez-Fernandez, S., 2005. Comparison of $\mathrm{N}$ losses (NO3-, N2O, NO) from surface applied, injected or amended (DCD) pig slurry of an irrigated soil in a Mediterranean climate. Plant and Soil 272, 313-325.

van der Meer, H. G., 2008. Optimising manure management for GHG outcomes. Australian Journal 
of Experimental Agriculture 48, 38-45.

van Groenigen, J. W., Kool, D. M., Velthof, G. L., Oenema, O. and Kuikman, P. J., 2006. Mitigating N2O emissions from urine patches in pastures. International Congress Series 1293, 347-350. van Groenigen, J. W., Kuikman, P. J., de Groot, W. J. M. and Velthof, G. L., 2005. Nitrous oxide emission from urine-treated soil as influenced by urine composition and soil physical conditions. Soil Biology \& Biochemistry 37, 463-473.

van Kessel, C., Venterea, R., Six, J., Adviento-Borbe, M. A., Linquist, B. and van Groenigen, K. J., 2013. Climate, duration, and $\mathrm{N}$ placement determine $\mathrm{N} 2 \mathrm{O}$ emissions in reduced tillage systems: a meta-analysis. Global Change Biology 19, 33-44.

VanderZaag, A. C., Gordon, R. J., Jamieson, R. C., Burton, D. L. and Stratton, G. W., 2009. Gas emissions from straw covered liquid dairy manure during summer storage and autumn agitation. Transactions of the Asabe 52, 599-608.

Velthof, G. L., Kuikman, P. J. and Oenema, O., 2003. Nitrous oxide emission from animal manures applied to soil under controlled conditions. Biology and Fertility of Soils 37, 221-230.

Velthof, G. L. and Oenema, O., 1997. Nitrous oxide emission from dairy farming systems in the Netherlands. Netherlands Journal of Agricultural Science 45, 347-360.

Venterea, R. T., Burger, M. and Spokas, K. A., 2005. Nitrogen oxide and methane emissions under varying tillage and fertilizer management. Journal of Environmental Quality 34, 1467-1477.

Venterea, R. T., Halvorson, A. D., Kitchen, N., Liebig, M. A., Cavigelli, M. A., Grosso, S. J. D., Motavalli, P. P., Nelson, K. A., Spokas, K. A., Singh, B. P., Stewart, C. E., Ranaivoson, A., Strock, J. and Collins, H., 2012. Challenges and opportunities for mitigating nitrous oxide emissions from fertilized cropping systems. Frontiers in Ecology and the Environment 10, $562-570$. 
Venterea, R. T. and Stanenas, A. J., 2008. Profile analysis and Modeling of reduced tillage effects on soil nitrous oxide flux. Journal of Environmental Quality 37, 1360-1367.

Ward, B., 2000. Nitrification and the marine nitrogen cycle. In: D. Kirchman (eds.) Microbial Ecology, pp. 427-454. New York: Wiley-Liss.

Watson, C., Laughlin, R. and McGeough, K., 2009. Modification of nitrogen fertilizers using inhibitors: opportunities and potentials for improving nitrogen use efficiency. In Proceedings No. 658. The International Fertilizer Society ed.^eds.). York.

Webb, J., Pain, B., Bittman, S. and Morgan, J., 2010. The impacts of manure application methods on emissions of ammonia, nitrous oxide and on crop response-A review. Agriculture Ecosystems \& Environment 137, 39-46.

Whitehead, D. C., 1995. Grassland Nitrogen. Wallingford, UK, CAB International.

Willers, H. C., Derikx, P. J. L., TenHave, P. J. W. and Vijn, T. K., 1996. Emission of ammonia and nitrous oxide from aerobic treatment of veal calf slurry. Journal of agricultural Engineering Research 63, 345-352.

Williams, E. J., Hutchinson, G. L. and Fehsenfel, F. C., 1992. $\mathrm{NO}_{\mathrm{x}}$ and $\mathrm{N}_{2} \mathrm{O}$ emissions from soil. Global Biogeochemical Cycles 6, 351-388.

WMO, 2012. The State of Greenhouse Gases in the Atmosphere Using Global Observations through 2011. WMO Greenhouse Gas Bulletin, Switzerland.

Wrage, N., Velthof, G. L., Beusichem, M. L. v. and Oenema, O., 2001. Role of nitrifier denitrification in the production of nitrous oxide. Soil Biology \& Biochemistry 33, $1723-1732$

Yamulki, S., 2006. Effect of straw addition on nitrous oxide and methane emissions from stored farmyard manures. Agriculture, Ecosystems \& Environment 112, 140-145. 
Yan, M. J., Humphreys, J. and Holden, N. M., 2013. The carbon footprint of pasture-based milk production: Can white clover make a difference? Journal of Dairy Science 96, 857-865.

Zaman, M. and Nguyen, M. L., 2012. How application timings of urease and nitrification inhibitors affect $\mathrm{N}$ losses from urine patches in pastoral system. Agriculture Ecosystems \& Environment 156, 37-48.

Zhang, G., Strom, J. S., Li, B., Rom, H. B., Morsing, S., Dahl, P. and Wang, C., 2005. Emission of ammonia and other contaminant gases from naturally ventilated dairy cattle buildings. Biosystems Engineering 92, 355-364.

Zhong, Z., Lemke, R. L. and Nelson, L. M., 2009. Nitrous oxide emissions associated with nitrogen fixation by grain legumes. Soil Biology \& Biochemistry 41, 2283-2291. 
Table 1. Net total $\mathrm{N}_{2} \mathrm{O}$ emissions during storage and after field application of differently treated dairy cattle slurry (given in $\mathrm{g} \mathrm{N}_{2} \mathrm{O}$ per $\mathrm{m}^{3}$ slurry) (Amon et al., 2006)

\begin{tabular}{lccccc}
\hline & Untreated & Separated & Digested & Straw cover & Aerated \\
\hline Storage & $20.2^{\mathrm{a}}$ & $9.0^{\mathrm{b}}$ & $28.5^{\mathrm{a}}$ & $42.2^{*}$ & $49.3^{*}$ \\
Storage-solid fraction & & 13.2 & & & \\
Field application & $3.8^{\mathrm{a}}$ & $6.4^{\mathrm{b}}$ & $2.7^{\mathrm{a}}$ & $10.3^{\mathrm{c}}$ & $4.9^{\mathrm{b}}$ \\
Total emission & 24.0 & 28.6 & 31.2 & 52.5 & 54.2 \\
\% Storage & 84.2 & 77.6 & 91.3 & 80.4 & 91.0 \\
\% Application & 15.8 & 22.4 & 8.7 & 19.6 & 9.0 \\
\hline
\end{tabular}

Different superscripts indicate significant differences at $p<0.05$ (separately for emissions during storage and after field application).

*No statistical comparison with untreated slurry was possible as the shape of the cumulated emissions curve was different from untreated slurry and the t-test for differences in regression parameters could not be applied. 
Table 2. The economic performance of systems of dairy production based on N-fertilized grass (FN) and grass-white clover (WC) grassland including sales, variable and fixed costs, and gross and net margin per ha (Humphreys et al., 2012).

\begin{tabular}{llll}
\hline System & FN & WC & P value \\
\hline Stocking density $\left(\mathrm{LU} \mathrm{ha}^{-1}\right)$ & 2.8 & 2.04 & $<0.05$ \\
Fertilizer $\mathrm{N}\left(\mathrm{kg} \mathrm{ha}^{-1}\right)$ & 246 & 90 & $<0.001$ \\
Milk sales $\left(€ \mathrm{ha}^{-1}\right)$ & 3168 & 2875 & $<0.05$ \\
Total sales $\left(€ \mathrm{ha}^{-1}\right)$ & 3530 & 3205 & $<0.05$ \\
Fertilizer $\mathrm{N}\left(€ \mathrm{ha}^{-1}\right)$ & 223 & 75 & $<0.001$ \\
Concentrate $\left(€ \mathrm{ha}^{-1}\right)$ & 312 & 275 & $\mathrm{NS}$ \\
Contractor charges $\left(€ \mathrm{ha}^{-1}\right)$ & 299 & 253 & $<0.01$ \\
Total variable costs $\left(€ \mathrm{ha}^{-1}\right)$ & 1400 & 1146 & $<0.01$ \\
Gross margin $\left(€ \mathrm{ha}^{-1}\right)$ & 2131 & 2058 & $\mathrm{NS}$ \\
Fixed costs $\left(€ \mathrm{ha}^{-1}\right)$ & 860 & 781 & $<0.05$ \\
Net margin $\left(€ \mathrm{ha}^{-1}\right)$ & 1271 & 1278 & $\mathrm{NS}$ \\
\hline
\end{tabular}


Table 3. Efficiency of farm $\mathrm{N}$ management options in lowering $\mathrm{N}_{2} \mathrm{O}$ emissions.

\begin{tabular}{|c|c|c|c|}
\hline Options & Efficiency & Comments & Refs \\
\hline \multicolumn{4}{|c|}{ Excreta patch management } \\
\hline $\begin{array}{l}\text { Reduced grazing } \\
\text { animal }\end{array}$ & + & $\begin{array}{l}\text { Economically not } \\
\text { acceptable }\end{array}$ & Humphreys 2008 \\
\hline Reduced grazing time & + & Depend on grazing time & $\begin{array}{l}\text { de Klein et al., 2006; Luo et al., } \\
\text { 2008b }\end{array}$ \\
\hline $\begin{array}{l}\text { Dietary manipulation } \\
\text { with low-protein forage }\end{array}$ & + & & $\begin{array}{l}\text { Luo et al., 2008a; Nielsen et al., } \\
2003\end{array}$ \\
\hline $\begin{array}{l}\text { Dietary manipulation } \\
\text { with salt }\end{array}$ & $?$ & Not supported by field study & $\begin{array}{l}\text { Van Groenigen et al., 2005; Kool } \\
\text { et al., 2006; Clough et al., } 2009\end{array}$ \\
\hline $\begin{array}{l}\text { Dietary manipulation } \\
\text { with hippuric acid }\end{array}$ & $?$ & Not supported by field study & $\begin{array}{l}\text { Ledgard et al., 2007; van } \\
\text { Groenigen et al., } 2006\end{array}$ \\
\hline Apply with NIs & + & & $\begin{array}{l}\text { Di et al., 2007; Dennis et al., 2008; } \\
\text { Selbie et al., } 2010\end{array}$ \\
\hline \multicolumn{4}{|l|}{ Fertilizer $\mathbf{N}$ management } \\
\hline $\begin{array}{l}\text { Fertilizer } N \text { type - } \\
\text { PCFs }\end{array}$ & + & & Akiyama et al., 2010 \\
\hline $\begin{array}{l}\text { Fertilizer } \mathrm{N} \text { type - } \\
\text { others }\end{array}$ & $?$ & $\begin{array}{l}\text { Depending on timing and } \\
\text { site conditions }\end{array}$ & $\begin{array}{l}\text { Bouwman et al., 2002; Stehfest } \\
\text { and Bouwman, 2006; Venterea et } \\
\text { al., } 2005\end{array}$ \\
\hline Timing of fertilization & $?$ & & $\begin{array}{l}\text { Phillips et al., 2009; Venterea et } \\
\text { al., } 2012\end{array}$ \\
\hline Fertilizer N placement & $?$ & $\begin{array}{l}\text { Effective in cropland, but } \\
\text { needs test in grassland }\end{array}$ & $\begin{array}{l}\text { Liu et al., 2006; Venterea et al., } \\
\text { 2008; van kessel et al., } 2013\end{array}$ \\
\hline Fertilizer $\mathrm{N}$ rate & + & $\begin{array}{l}\mathrm{N}_{2} \mathrm{O} \text { emissions can be } \\
\text { mitigated after reducing } \mathrm{N} \\
\text { fertilizer inputs to levels } \\
\text { that just satisfy crop needs }\end{array}$ & $\begin{array}{l}\text { Bouwman et al., 2002; Halvorson } \\
\text { et al., 2008; Hoben et al., 2011; } \\
\text { McSwiney et al., 2005; Rafique et } \\
\text { al., } 2011\end{array}$ \\
\hline Apply with NIs & + & Need additional cost & Akiyama et al., 2010 \\
\hline \multicolumn{4}{|l|}{ Manure management } \\
\hline $\begin{array}{l}\text { Use of bedding } \\
\text { materials }\end{array}$ & - & & $\begin{array}{l}\text { Groenestein et al., 1996; Thorman } \\
\text { et al., 2003; Zhang et al., } 2005\end{array}$ \\
\hline Storage as slurry & + & Need more space & $\begin{array}{l}\text { Sommer et al., 2000; Berg et al., } \\
\text { 2006; IPCC, } 2006\end{array}$ \\
\hline Slurry storage - cover & - & & $\begin{array}{l}\text { Sommer et al., 2000; Berg et al., } \\
\text { 2006; VanderZaag et al., } 2009\end{array}$ \\
\hline $\begin{array}{l}\text { Slurry storage - lower } \\
\mathrm{pH}\end{array}$ & + & & Berg et al., 2006 \\
\hline $\begin{array}{l}\text { Slurry storage - } \\
\text { treatment }\end{array}$ & $?$ & & $\begin{array}{l}\text { Amon et al., 2006; Beline et al., } \\
\text { 1999; Fangueiro et al., 2008; } \\
\text { Clemens et al., 2006; Loyon et al., } \\
\text { 2007; Willers et al., } 1996\end{array}$ \\
\hline
\end{tabular}


Solid manure -

anaerobic conditions

Solid manure - Straw ?

addition

Application - manure

?

type

Application - rate

Application - timing

Application - methods

$+$

?

?

Application - with NIs +

Use of biological $\mathbf{N}$ fixation

BNF
Chadwick et al., 2011; Chadwick

et al., 2005; Hansen et al., 2006

Brown et al., 2000; Sommer et al., 2000; Yamulki, 2006

Clemens et al., 2006; Chadwick et al., 2000

Similar to fertilizer $\mathrm{N}$

Similar to fertilizer $\mathrm{N}$

Webb et al., 2010; Sistani et al., 2010; Chadwick et al., 2011

Need additional cost

Akiyama et al., 2010

Li et al., 2011; Ruzjerez et al., 1994; Rochette et al., 2005; Jensen et al., 2012; Schils et al., 2005;

Yan et al., 2013

* PCFs denotes polymer-coated fertilizers

** “+”, "-" and "?" correspond positive, negative, and positive/negative efficiencies in lowering $\mathrm{N}_{2} \mathrm{O}$ emissions, respectively. 


\section{Figure legends:}

Fig. 1. Nitrogen cycling in grassland based systems showing $\mathrm{N}_{2} \mathrm{O}$ production. Open arrows represent soil $\mathrm{N}$ cycling processes (nitrification (1), denitrification (2) and nitrifier denitrification (3)). Solid arrows denote the relative size and direction of the $\mathrm{N}$ flows. Percentages indicate the estimated transfer of $\mathrm{N}$ from one compartment to the other compartment (modified from Oenema et al. (2005) and Wrage et al. (2001)). $\mathrm{N}_{2} \mathrm{O}$ production in soil also applies to the manure environment. $\mathrm{N}$ losses other than $\mathrm{N}_{2} \mathrm{O}$ are not shown. $\mathrm{BNF}-$ Biological $\mathrm{N}$ fixation. 


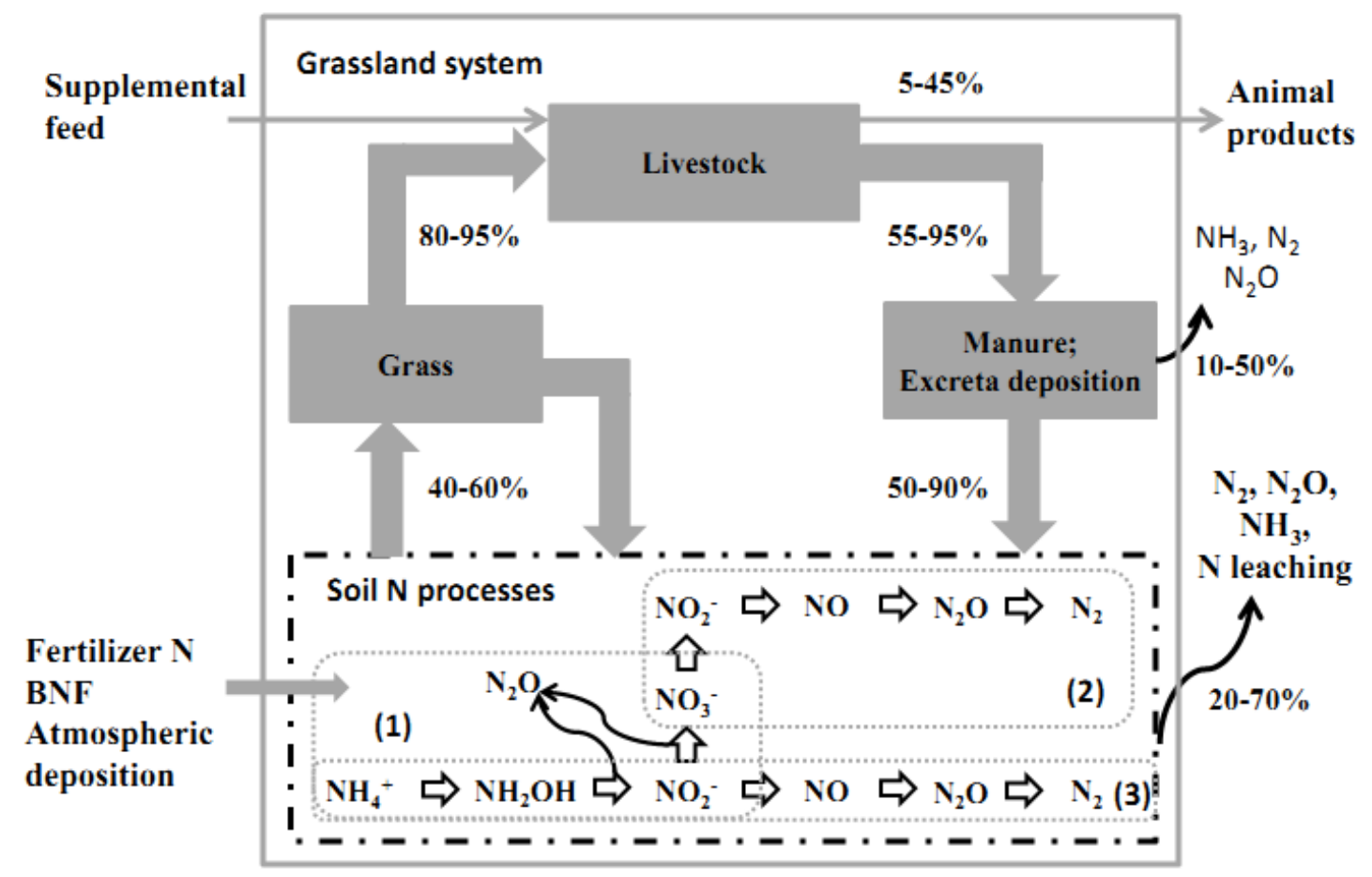

Fig. 1. Nitrogen cycling in grassland based systems showing $\mathrm{N}_{2} \mathrm{O}$ production. Open arrows represent soil $\mathrm{N}$ cycling processes (nitrification (1), denitrification (2) and nitrifier denitrification (3)). Solid arrows denote the relative size and direction of the $\mathrm{N}$ flows. Percentages indicate the estimated transfer of $\mathrm{N}$ from one compartment to the other compartment (modified from Oenema et al. (2005) and Wrage et al. (2001)). $\mathrm{N}_{2} \mathrm{O}$ production in soil also applies to the manure environment. $\mathrm{N}$ losses other than $\mathrm{N}_{2} \mathrm{O}$ are not shown. $\mathrm{BNF}-$ Biological $\mathrm{N}$ fixation. 